\title{
Going the distance: mapping mobility in the Kalahari Desert during the Middle Stone Age through multi-site geochemical provenancing of silcrete artefacts
}

David J. Nash a,b,*, Sheila Coulson ${ }^{\text {c }}$, Sigrid Staurset ${ }^{\text {c }}$, J. Stewart Ullyott a , Mosarwa Babutsi ${ }^{\text {d }}$, Martin P. Smith ${ }^{\text {a }}$

a School of Environment and Technology, University of Brighton, Lewes Road, Brighton BN2 4GJ, United Kingdom.

b School of Geography, Archaeology and Environmental Studies, University of the Witwatersrand, Private Bag 3, Wits 2050, South Africa.

c Institute of Archaeology, Conservation and History, University of Oslo, Blindernveien 11, 0315 Oslo, Norway.

d Department of National Museum and Monuments, 331 Independence Avenue, Gaborone, Botswana.

\section{* Corresponding author}

E-mail address: d.j.nash@ brighton.ac.uk (D.J. Nash)

Keywords: Raw material procurement, Silcrete provenancing, Middle Stone Age, Kalahari Desert, Human mobility, Lithic technology, Chaîne opératoire 


\section{Abstract}

This study utilises geochemical provenancing of silcrete raw materials, in combination with chaîne opératoire analyses, to explore lithic procurement and behavioural patterns in the northern Kalahari Desert during the Middle Stone Age (MSA). New data from the sites of Rhino Cave, Corner Cave, and $\neq \mathrm{Gi}$ in northwest Botswana, combined with earlier results from White Paintings Shelter, reveal that the long distance transport of silcrete for stone tool manufacture was a repeated and extensively used behaviour in this region. Silcrete was imported over distances of up to $295 \mathrm{~km}$ to all four sites, from locations along the Boteti River and around Lake Ngami. Significantly, closer known sources of silcrete of equivalent quality were largely bypassed. Silcrete artefacts were transported at various stages of production (as partially and fully prepared cores, blanks, and finished tools) and, with the exception of $\neq \mathrm{Gi}$, in large volumes. The import occurred despite the abundance of locally available raw materials, which were also used to manufacture the same tool types. On the basis of regional palaeoenvironmental data, the timing of the majority of silcrete import from the Boteti River and Lake Ngami is constrained to regionally drier periods of the MSA. The results of our investigation challenge key assumptions underlying predictive models of human mobility that use distance-decay curves and drop-off rates. MSA peoples in the Kalahari appear to have been more mobile than anticipated, and repeatedly made costly choices with regard to both raw material selection and items to be transported. We conclude that (i) base transport cost has been overemphasised as a restrictive factor in predictive models, and (ii) factors such as source availability and preference, raw material quality, and potential sociocultural influences significantly shaped prehistoric landscape use choices. 


\section{Introduction}

Studies of the distance over which lithic raw materials were transported from source to site form the foundation of our understanding of patterns of early human mobility through prehistoric landscapes. Mobility is influenced by a wide range of physical, socioeconomic, and sociocultural factors (see Table 1 and references therein). The ability to identify specific sources of raw material can yield data on both how far and where our ancestors travelled to obtain raw materials. When such information is combined with lithic analyses, it then becomes possible to gain insights into time-specific resource procurement and transport strategies. The most accurate means of determining source locations is through geochemical provenancing of lithic raw materials. A range of stone types have been used successfully in provenancing studies, including obsidian (e.g., Shackley, 1995; Roth, 2000; Negash and Shackley, 2006; Vogel et al., 2006; Eerkens et al., 2007; Negash et al., 2007; Morgan et al., 2009; Phillips and Speakman, 2009; Smith, 2010; Smith and Kielhofer, 2011; Ambrose, 2012; Freund, 2013), chert (e.g., Thacker and Ellwood, 2002; Evans et al., 2007; Milne et al., 2009; Parish, 2011; Gauthier et al., 2012; Speer, 2014; Boulanger et al., 2015), flint (e.g., Moroni and Petrelli, 2005; Navazo et al., 2008; Olofsson and Rodushkin, 2011; Ekshtain et al., 2014), dolerite (e.g., Gallello et al., 2016), quartzite (e.g., Pitblado et al., 2013), and, recently, silcrete (Nash et al., 2013a,b).

Studies using geochemical provenancing approaches have revealed, amongst other insights into early human behaviour, that Middle Stone Age (MSA) people in East and southern Africa were highly mobile and procured raw materials over distances of at least $220 \mathrm{~km}$ (e.g., Ambrose, 2001b; Negash and Shackley, 2006; Nash et al., 2013a). However, in many investigations, the analysed sample size is small (e.g., McBrearty, 1981, 1988; Merrick and Brown, 1984; Mehlman, 1989; Tykot, 2003) or limited to a specific tool type (e.g., Jones et al., 2003 [see Andrefsky, 2009 for a critique of this approach]; Smith, 2010). This impedes the formulation of broader observations or interpretations regarding the human behaviours linked to mobility. Other studies (e.g., Blumenschine et al., 2008; Monnier and McNulty, 2010; Brown, 2011; Porraz et al., 2013b) have 
attempted to match archaeological artefacts to potential lithic sources through a comparison of hand specimen characteristics (e.g. grain size, degree of cementation, level of translucence, type of cortex, colour, and the presence of rinds, patches, or specks in other colours). However, as noted by several studies (Tykot, 2003; Andrefsky, 2009; Nash et al., 2013a; Boulanger et al., 2015), this approach can be unreliable and may lead to the misidentification of prehistoric quarries, and hence transport distances, with implications for the interpretation of raw material procurement patterns.

Stone procurement patterns further form the basis for models of lithic reduction distance-decay curves, tool use/discard and retouch/recycling rates, planning depth, risk avoidance, and repeated behaviours indicating choice or preference (Table 1). These models, in turn, have been used to infer behaviours such as foraging range, territoriality, regional interaction, and seasonal or group cycles. The majority of models (e.g., see Brantingham, 2006 for summaries; Aubry et al., 2012; Browne and Wilson, 2013; Clarkson and Bellas, 2014) are founded upon two key assumptions, namely that (i) the closest raw material source would have been exploited for tool manufacture first, and (ii) all available sources would have been utilised. However, these assumptions have yet to be tested rigorously. Alternative scenarios have been proposed, whereby sociocultural features such as taboos, ancestral ties, resource ownership, colour preference, sources of power, raw material choice as a cultural marker, symbolic connotations tied to specific quarries, and knapping properties influenced both the choice and availability of procurement sites (Table 1).

In this study, we explore the validity of the key assumptions influencing present models of human mobility, through an analysis of lithic procurement and behavioural patterns at four MSA sites in the Kalahari Desert of northwest Botswana. Specifically, we utilise the novel combination of geochemical provenancing and chaîne opératoire investigation introduced by Nash et al. (2013a) to: (i) identify areas where MSA peoples acquired silcrete for tool manufacture; (ii) establish how far silcrete was transported from source to site; and (iii) assess whether stone was imported as raw material blocks, blanks, or prepared or partially prepared tools. We present new data for three sites: Rhino Cave and Corner Cave (both Tsodilo Hills), and $\neq \mathrm{Gi}$, a pan site near the Aha Hills (see Fig. 
1). These are compared against similar data from White Paintings Shelter, also at Tsodilo Hills (Nash et al., 2013a; Staurset and Coulson, 2014). The open setting of the northern Kalahari Desert, with its flat terrain, limited number of rock outcrops, and easily 'read' landscape, is ideally suited for this type of study. Combined, the results from these sites permit the mapping of prehistoric mobility on an unprecedented scale for southern Africa and challenge longstanding ideas about foraging strategies and resource procurement.

\section{Background to study sites}

\section{Rhino Cave}

Rhino Cave (RC) is located high on the northernmost ridge of Female Hill in the Tsodilo Hills (Fig. 1 inset). The interior of the cave is formed by a narrow fissure in the quartzite host-rock, and the present floor area of approximately $22 \mathrm{~m}^{2}$ is covered with thick aeolian deposits (Fig. 2a). The site, first excavated in the mid-1990s, contained a wealth of struck stone materials predominantly attributable to the MSA (Robbins et al., 1996a, 2000b). The initial excavations consisted of four consecutive $1 \mathrm{~m}^{2}$ squares positioned across the cave and dug to a maximum depth of $180 \mathrm{~cm}$ (Fig. 3). In the mid-2000s, new investigations were initiated to address a number of unresolved questions regarding the earlier MSA finds. As part of these studies, a single excavation unit positioned further into the cave was dug to a depth of $185 \mathrm{~cm}$ (Coulson et al., 2011). The combined investigations yielded an exceptionally rich MSA assemblage, in excess of 30,000 artefacts, containing a large number of diagnostic MSA points ( $n=149$ still available for study). Some $60 \%$ of diagnostic artefacts were made from non-locally acquired chert and silcrete, with the remainder consisting chiefly of locally available quartz and quartzite (Robbins et al., 2000b; Coulson et al., 2011; Staurset, 2014).

In both sets of excavations, the sediment was identified as consisting of brown aeolian sand with varying amounts of angular gravels. However, the excavated strata (Fig. 3a) have been reported 
somewhat differently (Robbins et al., 2000b; Coulson et al., 2011). In the initial excavations, the archaeological units were wedge-shaped, sloping, and appeared to be clearly divided (Robbins et al., 1996a, 2000b). In comparison, the more recent excavation revealed only one gradational stratigraphic divide, and the slope of the units was much less pronounced (Coulson et al., 2011). The MSA component was encountered at different depths: at 15-120 cm below surface in the 1990s investigations, and at 70-115 cm below surface in the more recent excavations. In both excavations, MSA material was still being recovered at the bottom of the pits. As the two excavations are very close, the contrasting sediment stratigraphy is surprising, and may indicate either differences in methodology or localised variation in cave taphonomy. Direct dating of the MSA layers at RC by the initial excavators proved difficult, necessitating a typological comparison to the MSA components of White Paintings Shelter (dates of $66.4 \pm 6.5$ and $94.3 \pm 9.4$ ka; Robbins et al., 2000a) and $\neq \mathrm{Gi}(77 \pm 11 \mathrm{ka}$; Brooks et al., 1990).

\section{Corner Cave}

Despite its name, Corner Cave (CC) is a rock shelter, situated on the southernmost end of Male Hill in the Tsodilo Hills (Figs. 1 and 2b). It is a small enclosure, filled with quartzite-schist slabs on which are found over 260 circular cupules (Walker, 2008, 2010). There is very little space inside the shelter, making the interior an unlikely candidate for habitation, especially as there are a number of other suitable overhangs and rock shelters in the immediate vicinity. In 2002-2003, two adjoining $1 \mathrm{~m}^{2}$ test squares were excavated in $5 \mathrm{~cm}$ mechanical layers directly in front of the opening of the shelter and the main cupule area. Here, an upper sandy deposit, with scant Later Stone Age (LSA) finds, overlay coarse sands and gravels containing an assemblage of materials assigned to the MSA on the basis of characteristic points $(n=11)$ and technology. Between these layers, an intermixed zone was encountered between 45-60 $\mathrm{cm}$ below surface (Coulson and Walker, 2002; Figure 3b). The total number of lithic finds was 5137, including prolific shatter from locally available quartz, together with locally available quartzite and non-locally acquired chert and 
silcrete. Chert and silcrete together comprised c. $25 \%$ of the assemblage (Staurset, 2014). As yet, no dates are available from this site.

$\neq G i$

$\neq \mathrm{Gi}$ is a pan edge site c. $7 \mathrm{~km}$ north of the Aha Hills and less than a kilometre from the Namibian border (Figs. 1 and 2c). Excavated in the 1970s (Brooks and Yellen, 1977; Brooks, 1978; Helgren and Brooks, 1983), $\neq$ Gi was the first Stone Age site in Botswana to be thoroughly investigated and subsequently dated (Brooks et al., 1990). Although over $100 \mathrm{~m}^{2}$ were excavated, this is estimated to be less than $20 \%$ of the total area of the site (Helgren and Brooks, 1983).

The stratigraphy of the site comprised LSA (units 1A-2B on Fig. 3c) and MSA (units 4-5) layers and an intermediate industry. Importantly, the upper MSA layer was capped by a $20-60 \mathrm{~cm}$ thick limestone unit (Helgren and Brooks, 1983), sufficiently indurated to require a pneumatic breaker drill during excavation (Kuman, 1989). This supports strongly the integrity of the divide between the MSA and LSA assemblages. The top of unit 4, immediately beneath the limestone, was thermoluminescence (TL) dated to $77 \pm 11 \mathrm{ka}$ (Brooks et al., 1990), arguably the most secure of the extant Botswana MSA age estimates.

Some 26,000 lithic finds (including 597 MSA points) were excavated from units 4 and 5 (Kuman, 1989). The raw material was chiefly chalcedony (69-71\%) and chert (20\%), with minor quartz, silcrete, and quartzite components (Kuman, 1989). Chert, jasper, chalcedony, and quartzite are reported to occur in both tabular form in local outcrops and in medium to large size cobbles in the conglomerate below the MSA horizons (Brooks et al., 2006). However, based on the high level of curation and recycling of artefacts by MSA peoples, it was suggested that the lithic raw material sources had not been immediately accessible, but were situated within a $100 \mathrm{~km}$ radius of the site (Kuman, 1989). The MSA assemblage from $\neq$ Gi exhibits strong technological similarities to that of $\mathrm{RC}$ in terms of both point production techniques and blank manufacture (Coulson et al., 2011; Staurset, 2014). 


\section{White Paintings Shelter}

As the results of geochemical provenancing and the analysis of lithics from White Paintings Shelter (WPS) are used for comparative purposes in this study, the site is described only briefly here. WPS is situated midway along the western side of Male Hill at Tsodilo Hills (Fig. 1). A 7 m deep sedimentary sequence was excavated during the late 1990s (Murphy, 1999; Robbins et al., 2000a), with the $3 \mathrm{~m}$ deep MSA component of the deposits yielding c. 7500 lithic artefacts. The MSA sediments have been optically stimulated luminescence (OSL) dated to $66.4 \pm 6.5$ and $94.3 \pm$ $9.4 \mathrm{ka}$, with a suggested basal deposit age in excess of $100 \mathrm{ka}$ (Ivester et al., 2010; Robbins and Murphy, 2011). However, recent refitting analyses (Staurset and Coulson, 2014) have identified considerable vertical and lateral movement of artefacts within the MSA sequence and, hence, raised doubts about the reliability of the dates and chronology. Some $55 \%$ of the excavated MSA artefacts were made from non-locally acquired chert and silcrete, with the remainder manufactured using locally available quartz and quartzite (Robbins and Murphy, 1998, 2011; Murphy, 1999; Robbins et al., 2000a; Donahue et al., 2004).

\section{Materials and methods}

Central to the success of any raw material provenancing study is the geochemical characterisation of both potential quarry sites and archaeological artefacts. This section outlines the methods used to develop these geochemical datasets, together with the statistical approach used in their subsequent analysis. Integral to this process is the selection of artefacts for sampling based on a chaîne opératoire investigation, also described here.

\section{Details of silcrete geochemical database}

For the purposes of this study, the database of silcrete chemistry included as supplementary material within Nash et al. (2013a) was utilised to characterise potential quarry sites. This dataset incorporates analyses of 86 samples from silcrete sites across northwest Botswana and northeast 
Namibia. The geographical distribution of sampling sites (Fig. 1) is described in detail by Nash et al. (2013a) and is, therefore, only outlined here. Note that we use the term 'site' here and throughout the paper to describe specific silcrete outcrops and 'locality' for larger areas of silcrete occurrence containing multiple outcrops.

All silcrete localities within an approximately $150 \mathrm{~km}$ radius of Tsodilo Hills were sampled during an extensive field campaign in August 2011, including localities along the Okavango River and within the Xaudum fossil valley. $\neq \mathrm{Gi}$ lies at the westernmost edge of this area. Samples were collected additionally at multiple sites within the extensive silcrete localities along the Boteti River and around Lake Ngami to the south of the Okavango Delta (Mallick et al., 1981; Shaw and Nash, 1998). All sampling sites were in primary context; unlike the Cape coastal zone of South Africa, the extremely low gradient of the Kalahari landscape precludes the large scale erosion of outcrops and, hence, the development of secondary sources at distances from their origin. Sites were footsurveyed prior to sampling, with normally at least three samples taken from each outcrop. For larger outcrops, multiple representative profiles were first logged and then sampled. In the rare instances where silcrete occurred as a scattered deposit, sites were foot-surveyed to determine the range of silicified material present, with representative material then sampled. A GPS reading was taken at each site.

The 2011 field campaign was founded on a review of previous literature, plus the benefit of local knowledge developed over the course of 20 years' field-based research into Kalahari duricrusts by the lead author. It encompassed all major topographic lows in northwest Botswana and northeast Namibia where silcrete was likely to outcrop—namely within the fossil valleys west of the Okavango Delta, along the Okavango Panhandle and River as far west as Rundu in Namibia, around the southern flank of Lake Ngami, and along the course of the Boteti River as far east as Xhumaga. The survey did not include the dune-covered areas between the fossil valleys west of the Okavango Delta. Silcrete has not been documented in these areas, and is unlikely, on the basis of our current understanding of non-pedogenic silcrete formation (cf. Nash and Ullyott, 2007), to have 
developed there. Further, as Nash et al. (2013a) note, if any silcrete is present within the dunefield, it is likely to have remained buried beneath tens of metres of dune sediments for the duration of the MSA. Similarly, the Okavango Delta itself was not explored. Despite extensive field research by Spike McCarthy and colleagues from the University of the Witwatersrand over the last 30 years, only weakly-developed incipient (i.e., early stage) silcrete formation has been identified at depth within Delta sediments (e.g., McCarthy and Ellery, 1985). Certainly, there are no surficial or shallow-buried outcrops of the sorts of indurated material required for stone tool manufacture anywhere within the area covered by Okavango Delta sediments at the present day. As a result, we consider it highly unlikely that we have missed any major silcrete localities.

In addition to geochemical analyses (described below), each of the 86 silcrete raw material samples was analysed in thin-section in order to determine a variety of petrological characteristics. These included the size range of incorporated mineral grains, the nature of these grains, the type and configuration of silica cements, and the diagenetic history of the material. This information was used to assess whether there were any spatial differences in silcrete fabrics and cement types that might influence their knapping properties and, hence, their potential use by MSA peoples.

\section{Field archaeological investigations}

As described in Nash et al. (2013a), a surface archaeological survey was conducted around each of the identified silcrete outcrops to establish whether sites were known and potentially used in prehistory. This survey included the identification of (i) any technologically distinct and, therefore, diagnostic lithic artefacts from the various Stone Age periods that may be present, (ii) evidence for the working of raw material, and (iii) any 'jettisoned' tools (Meltzer, 1989) that were manufactured in silcrete or other raw materials not found in that outcrop. No artefacts were collected and no excavations were undertaken. All silcrete sampling sites where diagnostic MSA finds were also identified are indicated by infilled symbols on Figure 1. 
In order to match artefacts from $\mathrm{RC}, \mathrm{CC}$, and $\neq \mathrm{Gi}$ to their potential sources, silcrete manufacturing waste flakes from the extant collection of archaeological materials for each site, housed at the Department of National Museum and Monuments, Gaborone, were sampled for geochemical analysis. Silcrete samples from CC and RC were selected following the same criteria and methods used previously at WPS (Nash et al., 2013a), in conjunction with a comprehensive chaîne opératoire study of the Tsodilo Hills MSA assemblages (Staurset, 2014). To ensure representativeness, two factors were considered: (i) the types of silcrete present in the assemblages, and (ii) the horizontal and vertical distribution of potential samples. The first of these factors was based on separating the lithics into raw material groups, with the aim of identifying artefacts likely to originate from the same block of raw material. This was done by initially separating all silcrete artefacts from the MSA layers, including debris, blanks, cores, and tools. These were then sorted into type groups and subgroups based on hand specimen characteristics, specifically grain size, degree of cementation, level of translucence, type of cortex, colour and presence of rinds, patches, specks, or patterns in other colours (see Supplementary Online Material [SOM] Tables S1-S2; see also Nash et al., 2013a). This proved to be relatively straightforward, as the silcretes from RC and $\mathrm{CC}$ are varied and often highly distinctive. The groups were then confirmed and refined through a chaîne opératoire study that included targeted refitting, before being checked by experts on Kalahari silcrete (lead author and contributor MB). Note that these groups were established to ensure that archaeological samples were representative and embedded in local production sequences, not as a means for provenancing silcrete based on visual characteristics.

After raw material groups were established, specimens were chosen to represent the variability within each of the type groups, with more samples included from groups with larger numbers of artefacts or greater variability. Finally, samples were selected to reflect as broad a horizontal and vertical spread as possible. At both sites, but particularly at $\mathrm{CC}$, there was a component of silcrete/chert composite material; usually a silcrete matrix with 1-4 mm glassy patches (SOM Table 
S1), which was included in this study. In total, 22 silcrete groups and subgroups were identified in the RC assemblage (see SOM Table S2) and 13 groups and subgroups in the excavated material from CC (SOM Table S1).

In addition to the 22 main silcrete groups, the RC assemblage further comprised many small groups $(n \leq 4)$ of silcrete artefacts. Often comprising 1-2 tools, large flakes, or blanks, these groups were so characteristic that if any additional material had been present in the excavated area, this would have been readily identifiable. However, at both sites, silcrete was imported at various stages in the manufacturing process: as partially prepared tools, blanks, cores, and larger blocks of raw material. The main production strategy in all groups was the production of MSA unifacial and bifacial points, chiefly on blanks produced by discoid, Levallois, or Kombewa technology.

Only artefacts that clearly belonged to silcrete type groups with MSA technological characteristics were considered for sampling. As CC is undated, the dating of RC is less secure, and subsurface artefact movement has been documented at WPS (Staurset and Coulson, 2014), particular care was taken to exclude any LSA artefacts. This separation was fairly straightforward, as the minor LSA components at both $\mathrm{CC}$ and RC chiefly comprise tools and debris from the production of characteristic microlithic points and thumbnail scrapers (Robbins et al., 2000b; Coulson et al., 2011; Staurset, 2014). Silcrete was rarely used for these purposes. The LSA microblade and bipolar technology differs markedly from MSA lithic production, and can be identified on debitage. A total of 26 silcrete artefacts were selected from CC (Fig. 4; Table 2) and 18 from RC (Fig. 5; Table 3) for geochemical analysis; the approximate stratigraphic position of each artefact is indicated on Figure 3. As the process used for geochemical analysis is destructive, the number of samples was kept to a minimum to ensure the integrity of the archaeological collection for future research.

The sample selection process for $\neq$ Gi differed to that used for the Tsodilo sites. As only a sample of the debris was retained from this site during excavation, a similar raw material study was not feasible. Instead, silcrete artefacts from the MSA layers (units 4 and 5 on Fig. 3c) were identified, 
and candidates selected to reflect hand specimen characteristics present across the range of available tools, cores, and debris. Of the 35 artefacts initially selected, 24 were deemed suitable for final analysis. The final samples are shown in Figure 6, with full details of each artefact given in Table 4. Although present in all layers, silcrete was a much less common raw material at $\neq \mathrm{Gi}$ compared to the Tsodilo Hills MSA sites.

During sample selection from all assemblages, only manufacturing waste flakes or flake fragments were considered. Pieces displaying evidence of patination or leaching were avoided, as this could indicate weathering post-burial and might impact upon chemical composition. Flakes and fragments displaying visual signs of fire-induced damage, such as cracking, crazing, potlids, colour change, and shrinkage, were similarly excluded. Where present within assemblages, such specimens were burnt to the point of cracking, beyond the stage where knapping quality would have been improved, and did not display the characteristic glossy sheen of intentional heat alteration (Coulson et al., 2011; Staurset, 2014). As noted previously (Nash et al., 2013b), at this stage, we would not recommend the use of our approach on artefacts that have been pre-treated in this way. Recent work by Schmidt et al. (2013) has shown, for example, that heat-treatment of silcrete leads to the loss of chemically-bound silanole water from silica minerals and the hardening of the material through the formation of new Si-O-Si bonds. These processes have the potential to affect the $\mathrm{SiO}_{2}$ content of samples. As yet, the impact of heating upon concentrations of other major and trace elements within silcrete (e.g., due to the dehydration of clay minerals) is not known. This topic is, however, presently under experimental investigation (by the lead author and Patrick Schmidt).

\section{Geochemical and statistical analyses}

The protocol used to determine the chemistry of samples within the silcrete geochemical database is described in Nash et al. (2013a, b). Archaeological manufacturing waste flakes from RC, $\mathrm{CC}$, and $\neq$ Gi were analysed using the same protocol by ALS Minerals, Seville, Spain, in 2013 and 2014. For brevity, the procedure is only summarised here. All waste flake samples were first fine-crushed, split, and then pulverised in an agate mill to $85 \%$ passing $75 \mu \mathrm{m}$ or better. Major 
oxide percentages and base metal concentrations ( $\mathrm{ppm}$ ) were determined using a Varian 700 series ICP-AES instrument; volatile, trace, and rare earth element concentrations using an Elan 9000 ICPMS; total C using a Leco induction furnace; and total S using a Leco sulphur analyser.

Results and detection limits for the 86 raw material samples within the silcrete geochemical database are included in the supplementary data of Nash et al. (2013a), along with data for the 14 artefacts analysed from WPS. Equivalent results for the 68 archaeological manufacturing waste flakes from RC, CC, and $\neq \mathrm{Gi}$ are given in the SOM Supplementary Dataset for this study. Quality control certificates SV13095984 (RC and CC) and SV13217190 ( $\neq \mathrm{Gi})$ issued by ALS Minerals on 26 July 2013 and 28 January 2014, respectively, apply to the analyses of archaeological materials.

Following Nash et al. (2013a, b), geochemical data were analysed by canonical discriminant analysis (CDA) using the SPSS statistics package. A total of 60 major, trace, rare earth, and volatile elements per sample were included within the analysis, with loss on ignition omitted due to issues of autocorrelation with $\mathrm{CaO}$. Where concentrations of elements were below detection limits, values were considered to be zero. Geochemical data for the 86 silcrete raw material samples were grouped according to geographical area (Boteti River, Lake Ngami, Okavango River, Xaudum Valley) prior to statistical analysis. These areas have been shown to form four distinct silcrete geochemical domains, due to regional differences in elemental composition, in turn controlled by variations in the mineralogy of the host sediments incorporated within the silcrete fabric (Nash et al., 2013a). Manufacturing waste flake samples from each archaeological site were left uncategorised and entered independently into the discriminant analysis in turn. CDA was used in preference to statistical techniques such as principal components analysis (PCA), since (i) the results of PCA are strongly affected by missing data and/or zero values within a dataset (in this case chemical elements that are below detection limits for some samples), and (ii) the use of PCA on a sample of less than 100 containing a large number of variables may produce statistically invalid results (Tabachnick and Fidell, 2001). 


\section{Results}

\section{Geochemical fingerprinting}

Plots of the first two functions arising from the CDA are shown in Fig. 7a-d. Each plot includes data for all the raw material samples, with results for artefacts from $\mathrm{CC}, \mathrm{RC}, \neq \mathrm{Gi}$, and WPS, respectively, superimposed as red triangles. The plots demonstrate clearly the statistical difference between the four silcrete geochemical domains in northwest Botswana and northeast Namibia, with raw material samples from the Boteti and Okavango rivers, Lake Ngami, and the Xaudum Valley falling into discrete, non-overlapping clusters. Levels of statistical significance for the raw material analyses are reported in Nash et al. (2013a).

Fig. 7a-d suggests strong visual overlap between the chemistry of many of the artefacts from CC and WPS and the raw material clusters, and less strong agreement for artefacts from $\mathrm{RC}$ and $\neq \mathrm{Gi}$. The plots are, however, two-dimensional representations of three-dimensional datasets (the CDA generated three discriminant functions; SOM Tables S3-S5) and, therefore, require more than visual interpretation. In order to assess with statistical confidence whether an archaeological waste flake originated from a particular source area, it is necessary to test if the flake falls within a critical distance of the centre of a raw material cluster (the group centroids shown on Fig. 7); this is determined using a measure called the squared Mahalanobis distance $\left(D^{2}\right)$. The $D^{2}$ value for each archaeological sample is given in SOM Tables S3-S5, for both the statistically closest and second closest raw material cluster. Waste flakes were allocated to a specific source area if $D^{2}$ was less than or equal to a critical value of 11.34. This value was calculated using the IDF.CHISQ(p,df) function in SPSS (assuming a cumulative probability of $p \leq 0.01$ and 3 degrees of freedom), and is a conservative measure of 'fit' to a cluster equivalent to the $99 \%$ level of statistical confidence. The statistically most probable source area for each waste flake is shown in Tables 2-4.

The results for CC (Fig. 7a, SOM Table S3) provide further evidence of the significance of silcrete from the Boteti River and Lake Ngami as a raw material resource during the MSA. The data 
exhibit a similar pattern to those for WPS (Nash et al., 2013a), plotting tightly around the respective group centroids on the discriminant function diagram, although the range of values for Function 1 is wider. On the basis of the $D^{2}$ values, 14 of the 26 waste flake samples fall statistically within a raw material cluster. Of these, six can be attributed to the Boteti River (samples CC 14, 17-19, 21, 26) and seven to Lake Ngami (CC 5, 6, 12, 13, 16, 20, 22; Table 2). One waste flake (CC 24) falls within the raw material cluster of silcrete from the Okavango River, the first of the 82 samples so far analysed using our new provenancing approach to do so. It is not possible to state with certainty whether the silcrete block from which flake CC 24 was struck was transported from the Shakawe area (sites BOT11/7 and 11/8, Botswana) or from near Shambyu (site NAM11/1, Namibia; Fig. 1), since the clusters of samples from these two areas partly overlap in Figure 7a. However, raw material samples from Shakawe exhibit more positive values for Function 1 than those from Shambyu, so it is statistically more likely that the silcrete block came from Shakawe. Regardless, this result confirms that Okavango silcrete was used for stone tool production during the MSA by the peoples who frequented Tsodilo Hills.

Simple visual inspection of Figure $7 \mathrm{~b}$ suggests that none of the 18 sampled archaeological waste flakes from RC fall within a raw material cluster. However, the chemistry of three flakes (RC 2, 8 , 13; Table 3) matches statistically that of silcrete from the Boteti River at the $99 \%$ confidence level (SOM Table S4). A similar pattern emerges for $\neq \mathrm{Gi}$. The results in Figure 7c indicate a much wider range of values for Function 2, suggesting greater chemical variability within the silcrete waste flake samples, with limited overlap between artefact distributions and the raw material clusters. However, two of the 24 waste flakes ( $\neq \mathrm{Gi} 15,34)$ match statistically the signature of silcretes from the Boteti River (SOM Table S5).

Considering these results as a whole, and presenting a highly conservative estimate of raw material procurement patterns, $\sim 23 \%$ of the sampled waste flakes from CC are statistically most likely to have been manufactured from silcrete blocks sourced from the Boteti River, $27 \%$ from Lake Ngami, and $\sim 4 \%$ from the Okavango River. By the same conservative measure, $\sim 17 \%$ of the 
silcrete artefacts from $\mathrm{RC}$ and $\sim 8 \%$ from $\neq \mathrm{Gi}$ appear to have been sourced from the Boteti River. These results are presented spatially in Figure 8. The figure highlights the importance of silcrete sources along the Boteti River for the peoples who used CC, WPS, and to a lesser extent, RC and $\neq \mathrm{Gi}$, during the MSA. The Boteti is approximately equidistant from both Tsodilo Hills and $\neq \mathrm{Gi}$, with site BOT 11/43 at c. $250 \mathrm{~km}$ and BOT 11/41 at c. $295 \mathrm{~km}$ (see Fig. 1). The distance over which silcrete was transported on the ground to Tsodilo and $\neq \mathrm{Gi}$, most likely avoiding the margins of the Okavango Delta swamps, would have been even greater. Outcrops around the southern margin of Lake Ngami were important silcrete raw material sources used at CC and WPS during the MSA, but not apparently at $\mathrm{RC}$ and $\neq \mathrm{Gi}$. Lake Ngami is c. $220 \mathrm{~km}$ in a direct line from Tsodilo Hills. Silcretes along the Okavango River, most likely those outcropping around Shakawe, represented a minor raw material source during the MSA for the users of CC only, despite being only c. $60 \mathrm{~km}$ distant from the site. Significantly, silcretes from the Xaudum Valley, c. $50 \mathrm{~km}$ from Tsodilo Hills and c. $80 \mathrm{~km}$ from $\neq \mathrm{Gi}$, are completely absent from the samples analysed.

A large number of artefacts from $\mathrm{CC}, \mathrm{RC}$, and $\neq \mathrm{Gi}$ could not be attributed with statistical confidence to specific source area clusters. Following the argument developed by Nash et al. (2013a) on the basis of data for WPS alone, it could be inferred that all of these outlying artefacts were knapped from silcrete blocks obtained beyond the sampling area. The availability of data for three additional sites, however, permits a more nuanced approach. The most extreme outliers (taken here as those samples with $D^{2}$ values in excess of 25.00 ; CC 1, 2, 4, 8, 9, 25; RC 1, 4, 5, 10, 14-16; $\neq$ Gi 3, 5-7, 9, 10, 12, 13, 18, 19, 21, 22, 24-30, 35) have chemistries so statistically different to silcretes from the Boteti and Okavango rivers, Lake Ngami, and the Xaudum Valley that they are most likely to have originated outside the raw material sampling area. In the case of $\neq \mathrm{Gi}-$ at the westernmost margin of the sampling area - it is possible that these silcretes originated in northeast Namibia. The remaining samples (CC 3, 7, 10, 11, 15, 23; RC 3, 6, 7, 9, 11, 12, 17, 18; $\neq \mathrm{Gi} 11,17$ ) all fall just beyond the critical $D^{2}$ value for the Boteti River and Lake Ngami raw material clusters. 
This makes it highly likely that they were sourced from either the Boteti or Lake Ngami, but this cannot be stated conclusively.

An interesting question is why — once extreme outliers are excluded — the remaining waste flake samples from $\mathrm{RC}$ and $\neq \mathrm{Gi}$ not attributed to source areas exhibit more negative values for Function 1, relative to both the Boteti River and Lake Ngami raw material clusters and the artefact data from CC and WPS (Fig. 7). The answer is most likely related to lower concentrations of the chemical elements that make the greatest contribution to the function in these samples (e.g., $\mathrm{Al}_{2} \mathrm{O}_{3}, \mathrm{~K}_{2} \mathrm{O}$, and $\mathrm{Lu}$; see Nash et al., 2013a). There are three possible reasons why such lower concentrations may occur. First, it may be that ion exchange has taken place since burial, such that the chemical fingerprint of individual artefacts has been altered relative to their raw silcrete source. This is, however, unlikely to have had a major impact on artefact chemistry, given low silcrete porosity values (see below) and our deliberate avoidance of obviously weathered materials during waste flake selection. Further, if ion exchange had occurred, the effects should be greatest for $\neq \mathrm{Gi}$ (a periodically flooded open-air site) and least for RC (a relatively dry cave site), with intermediate impacts for CC and WPS (sites beneath the overhangs of rock shelters) - this is not the case. Second, it may be that some of the artefacts from $\mathrm{RC}$ and $\neq \mathrm{Gi}$ were sourced from an unknown silcrete locality (or localities) within the study area with a different chemical signature. This is a possibility, but, given the statistical proximity of many samples to raw material clusters, the chemistry of any such locality must be only slightly different to that of the Boteti River or Lake Ngami. The third, and in our view most likely, reason is that the point-sampling approach used to construct the silcrete database has not captured fully the inhomogeneity of the silcrete localities around Lake Ngami and along the Boteti. In other words, while the main localities may have been characterised, not all sites within these localities have been sampled. Both the Boteti River and Lake Ngami contain extensive areas of outcrop; relatively limited variability in the modal proportions of clay and/or feldspar within the silcrete host sediment between outcrops could account for such chemical variation within samples. 


\section{Petrological analyses}

During the course of previous geochemical provenancing work, Nash et al. (2013a: 287) identified that silcretes from the Boteti River, Lake Ngami, Okavango River, and Xaudum Valley were "equally fine-grained and well-cemented, and... therefore likely to be of equivalent quality for tool manufacturing purposes" when viewed in outcrop and hand specimen. The results of petrological analyses confirm that the similarities between sites identified at these scales also extend to the silcrete micromorphology (Fig. 9). Silcretes from all four areas consist of well-rounded to sub-angular quartz grains, with minor proportions of feldspar and heavy minerals, cemented by silica. All samples were extremely well-indurated with very low (less than $1 \%$ ) pore space present. Microquartz, cryptocrystalline silica, and chalcedony were the dominant cement types (e.g., Fig. 9ac), with chalcedony cement present to a greater extent in some samples (e.g., Fig. 9c). All exhibit relatively simple microfabrics, confirming their formation in a non-pedogenic setting.

The major difference between samples was the size of host sediment grains. Unsurprisingly, given their deposition in low energy environments downstream of the Okavango Delta, the median grain size of quartz particles within silcretes from the Boteti River (Fig. 9a) and Lake Ngami (Fig. 9b) was small compared to those from the higher energy Okavango River (Fig. 9c) to the north. Samples from the Xaudum Valley (Fig. 9d), which rises close to the Botswana/Namibia border, contained a higher proportion of rock fragments in addition to rounded quartz grains, with a similar range of particle sizes to silcrete from the Okavango River. There were also minor differences in the relationship between host sediment grains and cements in some samples. Silcretes from the Boteti, Lake Ngami, and Okavango all exhibited a grain-supported fabric (sensu Summerfield, 1983), suggesting that they had developed by the simple cementation of a pre-existing sediment by silica. In contrast, samples from the Xaudum had, in places, a floating-fabric and a higher proportion of chalcedony cement (sometimes accompanied by patches of calcite; Fig. 9d), with the characteristics of the silcrete fabric suggesting that outcrops had formed by the gradual silicification of a valley calcrete (Nash and Shaw, 1998; Nash and McLaren, 2003; Nash et al., 2004; Nash and Ullyott, 
2007). Pending controlled experiments, it appears unlikely that the knapping properties of the silcretes from the four sampling areas would be affected by these slight differences in micromorphology.

\section{Discussion}

The results of geochemical fingerprinting make it possible to test key assumptions underlying models of human mobility related to lithic raw material procurement as outlined in the introduction. In the context of this study, these are: (i) that the closest silcrete source would have been exploited for tool manufacture first, and (ii) that all available silcrete sources would have been utilised. Given these scenarios, it would be expected that silcrete artefacts sourced from the Okavango River and Xaudum Valley would be well-represented in the archaeological assemblages from the Tsodilo Hills sites, with silcrete from the Xaudum dominating at $\neq \mathrm{Gi}$. Instead, where the provenance of artefacts can be ascertained, Figure 8 suggests a predominant use of distant silcrete sources over nearby quarries, with only one artefact sourced to the Okavango River (sample CC 24) and none to the Xaudum. This is surprising, as silcrete sampling sites along both the Okavango and Xaudum contained diagnostic MSA lithic material. For example, the quarries on the Okavango in northern Botswana (Fig. 1, sites BOT 11/7 and 11/8) were littered with well-made MSA points and other characteristic knapping debris from this period. This confirms that the silcrete sources in these areas were both known and used to obtain material for tool production during the MSA. However, at Tsodilo Hills, they were clearly a minor resource (in the case of Okavango silcrete) or apparently not used (Xaudum silcrete). Evidently, the two main assumptions underpinning models of human mobility and lithic raw material procurement do not always apply. This unexpected mode of raw material acquisition was found at all of the tested sites presented here and previously (Nash et al., 2013a), indicating that this behavioural pattern was common, and repeated, during the MSA in this region. The remainder of this paper will discuss possible explanatory factors for this behaviour, including a consideration of (i) raw material transport as part of lithic production strategies, (ii) 
variations in raw material source accessibility over time, and (iii) potential territories, foraging ranges, and other sociocultural factors. During the course of this discussion, the implications of our results for the understanding of prehistoric mobility, and models thereof, will be explored.

\section{Raw material transport as part of lithic production strategies}

While a number of factors are likely to have influenced human movement through the Kalahari landscape during the MSA, the limited number of lithic raw material sources in this region (see Fig. 8) would, presumably, have made their location an important factor in the shaping of foraging trips or seasonal/yearly rounds. Combined with the identification of long-distance import, this scarcity leads to two interconnected suppositions: (i) MSA people in this region had extensive knowledge of the landscape and its resources; and (ii) they were capable of pre-planning, anticipating needs for future stone-tool production, and adjusting their behavioural patterns to suit these needs (see also Nash et al., 2013a). The provenancing of silcrete artefacts in this study is not only significant in that it offers rare evidence of prehistoric mobility; it also provides access to the lithic production, tool usage, and wider behavioural patterns into which procurement strategies are embedded.

A common method for mapping prehistoric mobility by lithic raw material provenancing is through the use of behavioural models based on transport cost (see Table 1). In these models, the use of raw material from local or nearby sources is assumed to incur a lower transport cost and would, therefore, be expected to be more habitual than the exploitation of distant raw materials, regardless of whether the import is direct or via exchange between groups. In order to reduce the volume (and hence weight) of stone transported, lithic raw materials from more distant sources would also be expected to be smaller and/or at a later stage in the production process when compared to more locally derived materials (e.g., Newman, 1994; Beck et al., 2002; Clarkson and Bellas, 2014). Through the assessment of distance-decay curves or drop-off rates, behavioural models commonly predict the accumulation of early stage lithic production close to raw material quarries, with an increase in more heavily reduced or recycled tools correlated with increased distance from source (e.g., Blades, 1999; Close, 2000; Beck et al., 2002; Amick, 2007; Carter and 
Shackley, 2007; Blumenschine et al., 2008; Brown, 2011; Clarkson and Bellas, 2014; Ekshtain et al., 2014). This behavioural pattern has been identified, for example, in the MSA of East Africa (Ambrose, 2012), where the plotting of obsidian frequencies on distance-decay curves has revealed mobiliary and socioterritorial organisation strategies.

In addition to distance from site, knapping quality is a potential discriminating factor for the selection of raw material sources (e.g., Gould and Saggers, 1985; Bamforth, 1990; Brantingham et al., 2000; Jones et al., 2003; Minichillo, 2006; Wilson, 2007; Wurz, 2010; Porraz et al., 2013a; Gopher and Barkai, 2014; Pleurdeau et al., 2014). Various lithic production strategies require (or are adapted to) diverse raw material characteristics such as grain size, fracture modes, inclusions, and block size. The quality of the imported raw material when compared to locally available stone should then be expected to outweigh the cost of its transport (see also Gould and Saggers, 1985; Andrefsky, 1994, 2009).

Following these arguments, the imported silcrete at MSA sites in northwest Botswana would be expected to be: (i) volumetrically limited, (ii) in late stages of production or use, and (iii) of a significantly higher knapping quality than the locally available raw material. Raw materials from distant sources should not be embedded in on-site production but, rather, chiefly represent singular imports of finished tools (e.g., Close, 2000; Smith, 2010). Surprisingly, these predictions were either only partially matched, or contradicted, by the results of our investigations.

In terms of volume, the greater than expected preference for imported raw materials at Tsodilo Hills during the MSA has already been noted. At RC, more than 19,000 artefacts in non-locally available raw material (chiefly chert and silcrete) were recovered alongside locally available quartz and quartzite (Robbins et al., 2000b; Coulson et al., 2011; Staurset, 2014). The likely sourcing of archaeological silcrete samples to the Boteti River suggests the lengths to which MSA people at RC were willing to travel to acquire non-local raw material. The CC assemblage (c. 5100 artefacts) was dominated by quartz shatter, but non-local chert and silcrete still comprised c. $25 \%$ of the total (Staurset, 2014). Combined, the transport distance and the sheer volume of imported material at the 
Tsodilo Hills sites are far from indicative of singular, selective imports. Transport cost does not appear to have been the dominant determining factor in raw material acquisition practices at these sites.

The raw material acquisition pattern for $\neq$ Gi may have been different, as silcrete was used less regularly in lieu of chert, chalcedony, and quartzite (Kuman, 1989; Brooks et al., 2006). Only two archaeological samples from this site could be provenanced with statistical confidence - both to the Boteti River — while a larger number of samples probably originated outside the study area. A range of factors may have influenced resource acquisition strategies. As mentioned above, $\neq \mathrm{Gi}$ is located close to northeast Namibia, where potential silcrete localities remain unmapped. Unlike the Tsodilo Hills sites, $\neq \mathrm{Gi}$ is situated in an open landscape and archaeological evidence strongly supports its use as a specialised hunting site (Kuman, 1989; Brooks et al., 2006). In contrast, the Tsodilo sites have been interpreted as chiefly occupational (WPS and CC: Robbins et al., 2000a; Staurset, 2014) and ritual (RC: Coulson et al., 2011; Staurset, 2014) sites. Regardless, silcrete was imported over long distances to $\neq \mathrm{Gi}$.

In terms of stage of production and/or use, rather than being dominated by tool blanks or finished tools, as might be expected from predictive models of raw material acquisition, the recovered silcrete artefacts at RC and CC spanned almost the full chaîne opératoire cycle. This included cores in various stages of exhaustion: large flakes with partial cortex, debris from blank production, tool shaping, and retouching, along with finished tools. Examples of various production stages can be seen in Figure 10, showcasing characteristic samples from two silcrete groups, one from RC (likely provenanced to the Boteti River) and one from CC (to Lake Ngami). Based on the silcrete type groups established by hand specimen characteristics and refitting (SOM Tables S1-S2), artefacts in both locally and non-locally available raw materials were brought to these sites in a range of stages, as (partially prepared) cores, blanks, and tools. These finds contradict expectations from predictive models of raw material acquisition; transport costs would have been significantly lessened if only finished tools or blanks had been imported. As similar lithic import practices were 
found at nearby WPS (Nash et al., 2013a), these behaviours may be more common than previously thought.

The chaîne opératoire stages at $\neq \mathrm{Gi}$ cannot at present be compared directly to the Tsodilo sites, due to fewer samples being provenanced with statistical confidence and the more limited artefact categories available for study. In contrast to the Tsodilo Hills sites, the $\neq$ Gi point assemblage was generally highly curated and commonly exhibited evidence of resharpening or recycling (Helgren and Brooks, 1983; Kuman, 1989). This behaviour complies with predictive models for high transport costs, but here is evident on artefacts produced chiefly in presumably local raw material. The contrasts in curation could, potentially, be a result of the different site uses noted above.

In terms of quality, the difference in locally available and imported lithic raw materials is marked at all sites. At Tsodilo Hills, quartzite and quartz can be readily acquired, while chert, chalcedony, and jasper are reported to be locally available at $\neq \mathrm{Gi}$ (Brooks et al., 2006). As the production of heavily retouched points generally requires homogeneous lithic raw materials with a conchoidal fracture, the necessity for these materials would appear to be a likely reason for importing non-local stone to Tsodilo Hills. The locally available quartzite does not appear to have been sufficiently fine-grained to produce such points. However, Tsodilo Hills quartz is glassy, and numerous points in this material were found at both $\mathrm{CC}$ and RC. These points are generally of the same size and appear to have been manufactured using very similar techniques to those made in non-locally available chert and silcrete (Coulson et al., 2011). A similar pattern is visible at $\neq \mathrm{Gi}$, where there is no clear typological or technological difference between points in locally and nonlocally available raw material. Consequently, pending experimental replication and fracture testing (see conclusions), raw material import was apparently not necessary to produce the preferred MSA point types.

Overall, if models based purely on distance-decay curves or drop-off rates were used to explore the lithic record at $\mathrm{CC}$ and $\mathrm{RC}$, silcrete was used at these sites in a manner expected of local rather than imported lithic raw material. Silcrete has clearly been transported to the sites in large volumes, 
at various stages of production, and in combination with locally available raw material that apparently could be used to produce the same tools. In the case of $\neq \mathrm{Gi}$, the higher number of silcrete flakes from unknown sources results in a more complex picture. Nonetheless, long-distance import of silcrete is also evident at this site. This confirms the results from similar investigations at WPS (Nash et al., 2013a), allowing this behaviour to be considered a repeated regional pattern. These results highlight the need for the consideration of additional factors not included within predictive models when mapping prehistoric mobility patterns.

\section{Raw material source accessibility over time}

The majority of studies that utilise stone procurement patterns to reconstruct past human mobility predicate their analyses on the assumption that, unless exhausted, lithic raw material sources were always available. This is probably true for most environments and stone types. However, in the case of the Kalahari, silcrete outcrops occur most commonly in low-lying landscape positions (e.g., adjacent to rivers, within valleys, or at lake margins; see Nash and Ullyott, 2007) and, therefore, have the potential to become inaccessible as a result of changing hydroclimatic conditions. This can be seen today, where, for example, above average discharges through the Okavango Delta in recent years have led to flooding in the Boteti River and the inundation of the majority of silcrete outcrops along the river bed. Changes of this type during the MSA would have had major implications for raw material accessibility and, almost certainly, patterns of mobility.

The impact of past environmental changes upon resource accessibility can be explored through the well-resolved palaeoclimate records available for northern Botswana, notably chronologies derived from speleothems at Gcwihaba Cave ( $\sim 50 \mathrm{~km}$ south of $\neq \mathrm{Gi})$ and palaeolake shorelines within the Okavango-Makgadikgadi drainage system (see Fig. 11 and references therein). The chronology for Gcwihaba Cave comprises dated periods of speleothem growth and can be read essentially as a record of phases of wetter climate separated by inferred drier intervals. The chronology from the Okavango-Makgadikgadi drainage system, which includes the Okavango 
Delta, Lake Ngami, the Mababe, and Makgadikgadi depressions and low-lying areas along the Chobe River (Fig. 11 inset), requires more careful interpretation. The record comprises dated lake highstands within individual basins (dark blue bars), inferred 'mega-lake' phases when all of the basins were filled (light blue bars), and drier episodes when calcrete development took place (yellow hatched bars). However, it is not a direct reconstruction of regional rainfall variability, since the system is fed primarily by rain falling over the Okavango River catchment in Angola (Thomas and Shaw, 1991). Rises in lake levels during the MSA are therefore more likely to have reflected enhanced tropical rainfall further north than locally wetter conditions — although, as Burrough et al. (2009b) identify, the existence of large surface water bodies could lead to increased local moisture availability due to feedback effects. Subtle tectonic movements may also have impacted upon the low-gradient drainage network in the past and led to the diversion of flow from the Zambezi River towards the Palaeo-Makgadikgadi system (e.g., Nugent, 1990). Alternatively, as occurs today at times of enhanced flood, high discharges in the Zambezi and Chobe rivers may have caused a backing up of water behind the Chobe/Zambezi confluence and the reversal of flow towards the Palaeo-Makgadikgadi system (Shaw and Thomas, 1988; Thomas and Shaw, 1992; Burrough and Thomas, 2008).

Regardless of their specific cause, periods of higher lake levels would have had a major impact upon the accessibility of silcrete raw materials and, hence, mobility patterns. Plotting the altitude of silcrete sampling sites around the southern margin of the Ngami basin (Fig. 12), for example, allows the position of potential quarries to be compared against the palaeolake record for the MSA. During the four millennial-scale mega-lake phases centred on 105, 92, 65, and $39 \mathrm{ka}$ (thousands of years ago), when up to $66,000 \mathrm{~km}^{2}$ of present-day Botswana was flooded, water levels in the Ngami basin would have exceeded $945 \mathrm{~m}$ asl (White and Eckardt, 2006) and only the highest elevation silcrete outcrops on the southern lake rim (i.e., BOT11/1 and 11/3) would have remained exposed. Three of these mega-lake phases (centred on 105, 92, and $39 \mathrm{ka}$ ) are concordant with periods of speleothem growth at Gcwihaba Cave (e.g., Brook et al., 1998), suggesting widespread wetter conditions. 
During the highstands centred on $87,59,55$, and $46 \mathrm{ka}$, when water levels would have reached c. $936 \mathrm{~m}$ above sea level (asl) and an isolated lake was present within the Ngami basin (Burrough et al., 2007), sites BOT11/1-3 and the upper sections of BOT11/31 would have been accessible. However, all other sites would be under several metres of water.

Similar scenarios can be considered for silcrete exposures along the Boteti River. During the four mega-lake phases, all of the sampled potential quarry sites (at altitudes of 923-938 m asl) would have been underwater. It is less clear whether the same sites would have been accessible when lower level lakes occupied individual basins. However, by analogy with conditions over the last five years, it is likely that all silcrete outcrops along the Boteti would have been submerged. Periods of regional wetter climate not coincident with lake highstands (e.g., those centred on 77 and 45 ka within the Gcwihaba Cave record; Figure 11) are likely to have had little or no impact upon silcrete accessibility, although they may have influenced other aspects of resource availability such as the dispersal of game animals.

Considering the evidence as a whole, silcretes from the Boteti River and all but the highest level exposures around Lake Ngami can only have been available as raw material sources during drier interludes of the MSA when lake basins and rivers were not full. Given the distances over which silcrete was transported, populations must have been highly mobile during these periods. Alternative silcrete sources, possibly requiring the formulation of different mobility strategies, would have been needed during regional high lake phases. Our data suggests that these sources were not along the Okavango River or Xaudum, so unknown quarries beyond our sampling area are most likely. Such suggestions support our previous assertion that the MSA peoples who occupied WPS used silcrete from unknown sources during past wetter periods (Nash et al., 2013a).

Quite why the peoples who occupied the Tsodilo Hills and $\neq$ Gi during the MSA did not utilise silcrete from the Okavango River and Xaudum to any great extent is unclear. However, the reason is unlikely to be linked to past environmental changes. Sites BOT11/7 and 11/8 are at an altitude of $\sim 1002 \mathrm{~m}$ asl, well above the nearby Okavango River floodplain (c. $995 \mathrm{~m}$ asl), and are unlikely to 
have been inundated during wetter periods. Silcrete sites along the spring-fed Xaudum (997-998 m asl) are too far away from, and at too high an altitude above, the Okavango Delta to have been affected by backflooding. The Xaudum could only have contained water as a result of heavy regional rainfall. However, the only evidence for flooding dates to the LSA (Shaw et al., 1992), with no indication of either flow or standing water during the regional wetter episodes centred on 94, 73, and $45 \mathrm{ka}$ (Fig. 11). Clearly, other explanations are required.

\section{Potential territories, foraging ranges, and additional sociocultural factors}

Numerous studies have shown that human mobility can additionally be shaped by factors including territoriality, foraging strategies, and various sociocultural conventions (see references in Table 1). The considerable distances over which silcrete was transported, as indicated by our geochemical provenancing results, could suggest the presence of widespread social contacts and an expansive range in the Kalahari during the MSA (also see Goodyear, 1979; Ambrose and Lorenz, 1990; McBrearty and Brooks, 2000; Bamforth, 2009; Ellis, 2011; Sholts et al., 2012; Speth et al., 2013; Pearce and Moutsiou, 2014; Pearce, 2014; Boulanger et al., 2015). Clearly, with what was undoubtedly a low population density, the limits or boundaries of these ranges or potential territories would have been open and permeable. They may also have been larger than the maximum transport distances of almost $300 \mathrm{~km}$ determined by our results, as these only reflect the distances over which one raw material for tool production was moved. The existence of territorial limits could potentially account for a foraging strategy where apparently useable and equally knappable silcrete sources along the Okavango River and Xaudum were bypassed in favour of more distant quarries. If these quarries were outside the group's range limit, they may not have been readily accessible. The single sample (CC 24) from the undated MSA deposits at Corner Cave, which indicates exploitation of Okavango River silcrete, offers a tantalising glimpse of what could represent another period of MSA occupation or possibly an alteration in resource availability.

While we are still in the initial stages of mapping resource acquisition in the Kalahari, at present all four tested sites exhibit unexpectedly high levels of mobility. Our results indicate that the 
use of silcrete quarries along the Boteti River and at Lake Ngami was a repeated behavioural strategy during the MSA. Similar regular long-distance foraging journeys are widely reported amongst hunters and gatherers (e.g., Gould and Saggers, 1985; Meltzer, 1989; Malyk-Selivanova et al., 1998; Kaufman, 2002; Burke, 2006; Migal, 2006; Whallon, 2006; Amick, 2007; Ambrose, 2012; Aubry et al., 2012; Boulanger et al., 2015). For example, Gould and Saggers (1985) describe extremely large foraging areas from Australia, where raw materials were obtained from quarries almost $300 \mathrm{~km}$ away. Such regular or relatively frequent long-distance journeys would have provided a flow of information between what were, in all probability, widely scattered social groups during the MSA. This could, in turn, relate to the establishment and maintenance of a network of social relations that simultaneously would serve as a "safety net" or "buffer" in situations of resource scarcity (also see e.g., Whallon, 2006; Aubry et al., 2012; Stiner, 2013). Unfortunately, at this stage of our investigations, it is not possible to determine if the procurement of silcrete from the Boteti River and Lake Ngami was made by direct or indirect means; addressing this question remains a priority for future research.

A factor that has also been documented to affect hunter-gatherer lithic raw material import is the sociocultural significance of individual quarries. There are numerous studies of quarries considered to be places of importance in a landscape through ancestral ties, taboos, ownership, or even control of access (e.g., Binford and O'Connell, 1984; Meltzer, 1989; Paton, 1994; Ross et al., 2003). Ethnographic accounts (e.g., Taçon, 1991; Harrison, 2002; Stout, 2002; Ross et al., 2003) also offer examples of quarries possessing desirable characteristics and mythic significance (see below). Another point for consideration is the inherent power of the stone itself. Good examples of this are the well-known Aboriginal leilira blades (e.g., Taçon, 1991; Paton, 1994). These are unretouched blanks, each of which is named according to its quarry of extraction, with blades from different sources not allowed to be mixed. The sociocultural value of each blade is in the indispensable message of knowledge, ownership, power, access, and prestige it communicates. A related factor is the choice of stone as a cultural marker. One example is the selection of non-locally 
available stone for the production of backed artefacts from the Howiesons Poort level at Klasies River, South Africa (Wurz, 1999). Here, it is argued, the acquisition of distant raw materials added value to the composite artefacts through the cost of procurement as exchange items. As yet, these aspects of quarry and stone use exceed the limits of our investigation but may have been factors influencing our results.

A final factor that may also influence raw material source selection is colour preference (e.g., Taçon, 1991; Harrison, 2002; Stout, 2002; Barham, 2005; Eerkens et al., 2007). Lithic raw materials from RC, one of the sites in the present study, are argued to have been selected due to their vivid colouring (Coulson et al., 2011). In an example from the Australian ethnographic record, Taçon (1991) notes that certain outcrops of a particularly colourful, iridescent stone were thought to imbue a tool's manufacturer and owner with prestige through their association with powerful, dangerous forces. The colour was also linked to life forces considered to be brilliant, luminous, and iridescent, making hunting weapons produced from the stone more powerful and effective artefacts. In this instance, it was thought that the stone's killing power came from its source, for it was the "power within the stone which saps the life out of its target" (Taçon, 1991:203).

While it is not feasible to compare modern ethnographic data directly with MSA behavioural patterns, these points illustrate the variety and potential scope of sociocultural influences upon human lithic raw material acquisition. As has been demonstrated for the Kalahari sites in this study, a strict cost benefit approach fails to explain the prehistoric evidence, thus, indicating that even in the MSA these influences need to be considered.

\section{Conclusions}

This study has utilised the geochemical provenancing of silcrete raw materials, in combination with chaîne opératoire analyses, to explore patterns of human mobility in the northern Kalahari Desert during the MSA. New results from Rhino Cave, Corner Cave, and $\neq \mathrm{Gi}$, alongside data from 
White Paintings Shelter (Nash et al., 2013a), reveal that the long-distance transport of silcrete from quarries along the Boteti River and around Lake Ngami was a repeated and extensively-used strategy for resource procurement in this region, particularly for the MSA occupants of Tsodilo Hills. Silcrete was imported over long distances to all four sites, despite the availability of local knappable raw materials (which were also used at all sites) and closer sources of silcrete of equivalent quality (which were largely bypassed). Further, it was imported at various stages of production (as cores, blanks, and finished tools) and, with the exception of $\neq \mathrm{Gi}$, in large volumes. Palaeoenvironmental data constrain the timing of the majority of silcrete import from the Boteti and Lake Ngami to regionally drier periods. Further testing is now needed to determine whether the behavioural patterns identified are a characteristic of the MSA in the northern Kalahari only or have a wider distribution. The knapping capabilities of silcrete from various sources in the study area also require experimental replication and mechanical testing to determine conclusively that material properties were not a factor influencing silcrete choice.

The data presented here provide a unique opportunity to rigorously test assumptions underpinning the understanding of lithic transport and patterns of early human mobility. Our results challenge two of the key underlying features of predictive models using distance-decay curves and drop-off rates, and suggest that factors besides transport costs and socioeconomy should be considered when mapping human mobility. In addition to being more mobile than would be anticipated, MSA peoples in the Kalahari appear to have repeatedly made unexpected, costly choices with regard to raw material selection and items to be transported. The drive behind these choices cannot be explained by current predictive models, suggesting that base transport cost has been overemphasised as a restrictive factor. This study illustrates the need to include factors such as source availability/accessibility, raw material quality in relation to lithic production, and potential sociocultural influences for models to reflect more accurately prehistoric landscape use choices.

The power of our approach lies in the joint application of geochemical sourcing with chaîne opératoire analysis. This permits the testing of samples embedded within on-site production 
sequences, and makes it possible to ascertain the stages of artefact import within commonplace tool production (as opposed to the import of singular tools or blanks in non-local material). The application of a similar approach to other areas of southern Africa, and to timescales beyond the MSA, would offer unprecedented opportunities for understanding landscape use, behavioural adaptation, and the timing of human occupations, and for the mapping of long-term changes in human and hominin mobility.

\section{Acknowledgements}

This research was funded by the University of Brighton with additional support to SC and SS from the University of Oslo. Fieldwork was carried out under Government of Botswana research permit EWT 8/36/4 XV (25) with extension EWT 8/36/4 XXI (36). Archaeological samples were released under export permits NM 6/1/1 (38) for White Paintings Shelter, NM 6/1/1 (68) for Rhino Cave, NM 6/1/1 (61) for Corner Cave, and NM 6/2/1 II (65) for $\neq$ Gi. Philip Segadika and the staff at the Department of National Museum and Monuments, Gaborone, are thanked for their support and access to archaeological collections. Trevor Thomas is thanked for assistance with field logistics and Peter Lyons for help with sample preparation. Geochemical analyses were undertaken by ALS Minerals, Seville, Spain. Frank Eckardt (University of Cape Town) is thanked for his analysis of SRTM1 data used in the creation of Figure 12. Finally, we are grateful to the Associate Editor and three anonymous reviewers whose insightful comments helped improve the manuscript. 


\section{References}

Akerman, K., 2007. To make a point: Ethnographic reality and the ethnographic and experimental replication of Australian macroblades known as leilira. Australian Archaeology 64, 23-34.

Ambrose, S.H., Lorenz, K.G., 1990. Social and ecological models for the Middle Stone Age in southern Africa. In: Mellars, P. (Ed.), The Emergence of Modern Humans. Edinburgh University Press, Edinburgh, pp. 3-33.

Ambrose, S.H., 2001a. Middle and Later Stone Age settlement patterns in the Central Rift Valley, Kenya: comparisons and contrasts. In: Conard, N.J. (Ed.), Settlement Dynamics of the Middle Paleolithic and Middle Stone Age. Kerns Verlag, Tübingen, pp. 21-43.

Ambrose, S.H., 2001b. Paleolithic technology and human evolution. Science 291, 1748-1753.

Ambrose, S.H., 2002. Small things remembered: origins of early microlithic industries in SubSaharan Africa. In: Kuhn, S.L., Elston, R.G. (Eds.), Thinking Small: Global Perspectives on Microlithization. American Antropological Association, Washington, D.C., pp. 90-30.

Ambrose, S.H., 2006. Howiesons Poort lithic raw material procurement patterns and the evolution of modern human behavior: A response to Minichillo (2006). Journal of Human Evolution 50, 365369.

Ambrose, S.H., 2012. Obsidian dating and source exploitation studies in Africa. Implications for the evolution of human behavior. In: Liritzis, I., Stevenson, C.M. (Eds.), Obsidian and ancient manufactured glasses. University of New Mexico Press, pp. 56-72.

Amick, D.S., 2007. Investigating the behavioural causes and archaeological effects of lithic recycling. In: McPherron, S.P. (Ed.), Tools versus Cores: Alternative Approaches to Stone Tool Analysis. Cambridge Scholars Publishing, Newcastle, pp. 223-252.

Andrefsky, W., 2007. The application and misapplication of mass analysis in lithic debitage studies. Journal of Archaeological Science 34, 392-402.

Andrefsky, W.J., 1994. Raw-material availability and the organization of technology. American Antiquity 59, 21-34.

Andrefsky, W.J., 2009. The analysis of stone tool procurement, production, and maintenance. Journal of Archaeological Research 17, 65-103.

Aubry, T., Luís, L., Mangado Llach, J., Matias, H., 2012. We will be known by the tracks we leave behind: Exotic lithic raw materials, mobility and social networking among the Côa Valley foragers (Portugal). Journal of Anthropological Archaeology 31, 528-550.

Baales, M., 2001. From lithics to spatial and social organization: interpreting the lithic distribution and raw material composition at the final Palaeolithic site of Kettig (Central Rhineland, Germany). Journal of Archaeological Science 28, 127-141.

Bamforth, D.B., 1990. Settlement, raw-material, and lithic procurement in the central Mojave Desert. Journal of Anthropological Archaeology 9, 70-104.

Bamforth, D.B., 2009. Projectile points, people, and Plains Paleoindian perambulations. Journal of Anthropological Archaeology 28, 142-157. 
Barham, L.S., 2005. Red and yellow and pink and...brown. University of Liverpool Research Intelligence May 05, 4.

Barton, C.M., Riel-Salvatore, J., 2014. The formation of lithic assemblages. Journal of Archaeological Science 46, 334-352.

Barut, S., 1994. Middle and Later Stone Age lithic technology and land use in East African savannas. African Archaeological Review 12, 43-72.

Beck, C., Taylor, A.K., Jones, G.T., Fadem, C.M., Cook, C.R., Millward, S.A., 2002. Rocks are heavy: transport costs and Paleoarchaic quarry behavior in the Great Basin. Journal of Anthropological Archaeology 21, 481-507.

Binford, L.R., 1979. Organization and formation processes: looking at curated technologies. Journal of Anthropological Research 35, 255-273.

Binford, L.R., 1980. Willow smoke and dogs' tails: hunter-gatherer settlement systems and archaeological site formation. American Antiquity 45, 4-20.

Binford, L.R., O'Connell, J.F., 1984. An Alyawara Day-the stone quarry. Journal of Anthropological Research 40, 406-432.

Blades, B.S., 1999. Aurignacian lithic economy and early modern human mobility: new perspectives from classic sites in the Vézère valley of France. Journal of Human Evolution 37, 91120.

Blumenschine, R.J., Masao, F.T., Tactikos, J.C., Ebert, J.I., 2008. Effects of distance from stone source on landscape-scale variation in Oldowan artifact assemblages in the Paleo-Olduvai Basin, Tanzania. Journal of Archaeological Science 35, 76-86.

Boulanger, M.T., Buchanan, B., O'Brien, M.J., Redmond, B.G., Glascock, M.D., Eren, M.I., 2015. Neutron activation analysis of 12,900-year-old stone artifacts confirms 450-510+ km Clovis toolstone acquisition at Paleo Crossing (33ME274), northeast Ohio, USA. Journal of Archaeological Science 53, 550-558.

Brantingham, P.J., 2003. A neutral model of stone raw material procurement. American Antiquity 68, 487-509.

Brantingham, P.J., 2006. Measuring forager mobility. Current Anthropology 47, 435-459.

Brantingham, P.J., Olsen, J.W., Rech, J.A., Krivoshapkin, A.I., 2000. Raw material quality and prepared core technologies in Northeast Asia. Journal of Archaeological Science 27, 255-271.

Brook, G.A., Cowart, J.B., Marais, E., 1996. Wet and dry periods in the southern African summer rainfall zone during the last $300 \mathrm{kyr}$ from speleothem, tufa and sand dune age data. Palaeoecology of Africa 24, 147-158.

Brook, G.A., Cowart, J.B., Brandt, S.A., Scott, L., 1997. Quaternary climatic change in southern and eastern Africa during the last $300 \mathrm{ka}$ : the evidence from caves in Somalia and the Transvaal region of South Africa. Zeitschrift für Geomorphologie NF Supplementband 108, 15-48.

Brook, G.A., Cowart, J.B., Brandt, S.A., 1998. Comparison of Quaternary environmental change in eastern and southern Africa using cave speleothem, tufa and rock shelter sediment data. In: 
Alsharan, A., Glennie, K.W., Wintle, G.L., Kendall, C.G.S. (Eds.), Quaternary Deserts and Climate Change. Balkema, Rotterdam, pp. 239-250.

Brooks, A.S., 1978. A note on the Late Stone Age features at $\neq$ Gi: analogies from historic San hunting practices. Botswana Notes and Records 10, 1-3.

Brooks, A.S., Yellen, J.E., 1977. Archeological excavations at $\neq$ Gi: A preliminary report on the first two field seasons. Botswana Notes and Records 9, 21-30.

Brooks, A.S., Hare, P.E., Kokis, J.E., Miller, G.H., Ernst, R.D., Wendorf, F., 1990. Dating Pleistocene archeological sites by protein diagenesis in ostrich eggshell. Science 248, 60-64.

Brooks, A.S., Yellen, J.E., Nevell, L., Hartman, G., 2006. Projectile technologies of the African MSA: Implications for modern human origins. In: Hovers, E., Kuhn, S.L. (Eds.), Transitions Before the Transition. Evolution and Stability in the Middle Paleolithic and Middle Stone Age. Springer, New York, pp. 233-256.

Brown, K.S., 2011. The Sword in the Stone: Lithic Raw Material in the Middle Stone Age at Pinnacle Point Site 5-6, Southern Cape, South Africa. Ph.D. Dissertation, University of Cape Town.

Brown, K.S., Marean, C.W., Herries, A.I.R., Jacobs, Z., Tribolo, C., Braun, D., Roberts, D.L., Meyer, M.C., Bernatchez, J., 2009. Fire as an engineering tool of early modern humans. Science $325,859-862$.

Browne, C.L., Wilson, L., 2013. Evaluating inputs to models of hominin raw material selection: map resolution and path choices. Journal of Archaeological Science 40, 3955-3962.

Burke, A., 2006. Paleoindian ranges in northeastern North America based on lithic raw materials sourcing. In: Bressy, C., Burke, A., Chalard, P., Martin, H. (Eds.), Notions De Territoire Et De Mobilité: Exemples De L'Europe Et Des Premières Nations En Amérique Du Nord Avant Le Contact Européen. Études et Recherches Archéologiques de l'Université de Liège, Liège, pp. 7789.

Burney, D.A., Brook, G.A., Cowart, J.B., 1994. A Holocene pollen record for the Kalahari Desert of Botswana from a U-series dated speleothem. The Holocene 4, 225-232.

Burrough, S.L., Thomas, D.S.G., Shaw, P.A., Bailey, R.M., 2007. Multiphase Quaternary highstands at Lake Ngami, Kalahari, northern Botswana. Palaeogeography Palaeoclimatology Palaeoecology 253, 280-299.

Burrough, S.L., Thomas, D.S.G., 2008. Late Quaternary lake-level fluctuations in the Mababe Depression: Middle Kalahari palaeolakes and the role of Zambezi inflows. Quaternary Research 69, $388-403$.

Burrough, S.L., Thomas, D.S.G., Singarayer, J.S., 2009a. Late Quaternary hydrological dynamics in the Middle Kalahari: Forcing and feedbacks. Earth-Science Reviews 96, 313-326.

Burrough, S.L., Thomas, D.S.G., Bailey, R.M., 2009b. Mega-Lake in the Kalahari: A late Pleistocene record of the Palaeolake Makgadikgadi system. Quaternary Science Reviews 28, 1392 1141.

Carter, T., Shackley, M., 2007. Sourcing Obsidian from Neolithic Çatalhöyük (Turkey) using energy dispersive x-ray fluorescence. Archaeometry 49, 437-454. 
Clarkson, C., Bellas, A., 2014. Mapping stone: using GIS spatial modelling to predict lithic source zones. Journal of Archaeological Science 46, 324-333.

Close, A.E., 2000. Reconstructing Movement in Prehistory. Journal of Archaeological Method and Theory 7, 49-77.

Cooke, H.J., 1975. The palaeoclimatic significance of caves and adjacent landforms in Western Ngamiland, Botswana. The Geographical Journal 141, 430-444.

Cooke, H.J., 1984. The evidence from northern Botswana of late Quaternary climatic change. In: Vogel, J.C. (Ed.), Late Cainozoic Palaeoclimates of the Southern Hemisphere. Balkema, Rotterdam, pp. 265-278.

Cooke, H.J., Verhagen, B.T., 1977. The dating of cave development: an example from Botswana. Proceedings of the Seventh International Speleological Congress, Sheffield, pp. 122-124.

Cottrell, M.G., 1985. Tomato Springs: The identification of a jasper trade and production center in Southern California. American Antiquity 50, 833-849.

Coulson, S., Walker, N., 2002. Report on Archaeological Fieldwork 2002. The University of Botswana and the University of Troms $\varnothing$ Collaborative Programme for San/Basarwa Research (NUFU PRO 20/96), Gaborone/Troms $\varnothing$.

Coulson, S., Staurset, S., Walker, N., 2011. Ritualized behavior in the Middle Stone Age: evidence from Rhino Cave, Tsodilo Hills, Botswana. PaleoAnthropology 2011, 18-61.

Dillian, C.D., White, C.L., 2010. Introduction: perspectives on trade and exchange In: Dillian, C.D., White, C.L. (Eds.), Trade and exchange: archaeological studies from history and prehistory. Springer, New York, pp. 3-16.

Donahue, R.E., Murphy, M.L., Robbins, L.H., 2004. Lithic microwear analysis of Middle Stone Age artifacts from White Paintings Rock Shelter, Botswana. Journal of Field Archaeology 29, 155163.

Eerkens, J.W., Ferguson, J.R., Glascock, M.D., Skinner, C.E., Waechter, S.A., 2007. Reduction strategies and geochemical characterization of lithic assemblages: a comparison of three case studies from western North America. American Antiquity 72, 585-597.

Ekshtain, R., Malinsky-Buller, A., Ilani, S., Segal, I., Hovers, E., 2014. Raw material exploitation around the Middle Paleolithic site of 'Ein Qashish. Quaternary International 331, 248-266.

Ellis, C., 2011. Measuring Paleoindian range mobility and land-use in the Great Lakes/Northeast. Journal of Anthropological Archaeology 30, 385-401.

Evans, A.A., Wolframm, Y.B., Donahue, R.E., Lovis, W.A., 2007. A pilot study of "black chert" sourcing and implications for assessing hunter-gatherer mobility strategies in northern England. Journal of Archaeological Science 34, 2161-2169.

Féblot-Augustins, J., 1993. Mobility strategies in the Late Middle Palaeolithic of Central Europe and Western Europe: Elements of stability and variability. Journal of Anthropological Archaeology $12,211-265$.

Féblot-Augustins, J., 1997. Middle and Upper Palaeolithic raw material transfers in western and central Europe: assessing the pace of change. Journal of Middle Atlantic Archaeology 13, 57-90. 
Féblot-Augustins, J., 1999. La mobilité des groupes paléolithiques. Bulletins et Mémoires de la Société d'anthropologie de Paris 11, 219-260.

Fernandes, P., Raynal, J.-P., Moncel, M.-H., 2008. Middle Palaeolithic raw material gathering territories and human mobility in the southern Massif Central, France: first results from a petroarchaeological study on flint. Journal of Archaeological Science 35, 2357-2370.

Freund, K.P., 2013. An assessment of the current applications and future directions of obsidian sourcing studies in archaeological research. Archaeometry 55, 779-793.

Gallello, G., Orozco, T., Pastor, A., de la Guardia, M., Bernabeu, J., 2016. Regional provenance of dolerite prehistoric objects through mineral analysis. Microchemical Journal 124, 167-174.

Gauthier, G., Burke, A.L., Leclerc, M., 2012. Assessing XRF for the geochemical characterization of radiolarian chert artifacts from northeastern North America. Journal of Archaeological Science $39,2436-2451$.

Geneste, J., 1989. Economie des ressources lithiques dans le Moustérien du sud-ouest de la France. L'homme de Néandertal 6, 75-97.

Goodyear, A.C., 1979. A hypothesis for the use of cryptocrystalline raw materials among PaleoIndian groups of North America. Research Manuscript Series. Book 127. The South Carolina Institute of Archeology and Anthropology_-University of South Carolina, 1-15.

Gopher, A., Barkai, R., 2014. Middle Paleolithic open-air industrial areas in the Galilee, Israel: The challenging study of flint extraction and reduction complexes. Quaternary International 331, 95102.

Gould, R.A., Saggers, S., 1985. Lithic procurement in Central Australia: A closer look at Binford's idea of embeddedness in archaeology. American Antiquity 50, 117-136.

Harrison, R., 2002. Archaeology and the colonial encounter: Kimberley spearpoints, cultural identity and masculinity in the north of Australia. Journal of Social Archaeology 2, 352-377.

Helgren, D.M., Brooks, A.S., 1983. Geoarchaeology at Gi, a Middle Stone Age and Later Stone Age Site in the Northwest Kalahari. Journal of Archaeological Science 10, 181-197.

Ivester, A.H., Brook, G.A., Robbins, L.H., Campbell, A.C., Murphy, M.L., Marais, E., 2010. A sedimentary record of environmental change at Tsodilo Hills White Paintings Rock Shelter, Northwest Kalahari Desert, Botswana. In: Runge, J. (Ed.), African Palaeoenvironments and Geomorphic Landscape Evolution. CRC Press, London, pp. 53-78.

Jones, G.T., Beck, C., Jones, E.E., Hughes, R.E., 2003. Lithic source use and paleoarchaic foraging territories in the Great Basin. American Antiquity 68, 5-38.

Kaufman, D., 2002. Redating the social revolution: The case for the Middle Paleolithic. Journal of anthropological research 58, 477-492.

Kelly, R.L., 1988. The three sides of a biface. American Antiquity 53, 717-734.

Koerper, H.C., Fife, D.L., Singer, C.A., Ericson, J.E., 1987. Comments on Cottrell's long distance jasper trade hypothesis: In defense of Renfrew's trade models. American Antiquity 52, 623-630. 
Kuhn, S.L., 2004. Upper Paleolithic raw material economies at Üçağizli cave, Turkey. Journal of Anthropological Archaeology 23, 431-448.

Kuman, K.A., 1989. Florisbad and $\neq$ Gi: the contribution of open-air sites to study of the Middle Stone Age in southern Africa. PhD dissertation, University of Pennsylvania.

Mallick, D., Habgood, F., Skinner, A., 1981. A geological interpretation of Landsat imagery and air photography of Botswana. HMSO, London.

Malyk-Selivanova, N., Ashley, G.M., Gal, R., Glascock, M.D., Neff, H., 1998. Geologicalgeochemical approach to "sourcing" of prehistoric chert artifacts, northwestern Alaska. Geoarchaeology 13, 673-708.

Marwick, B., 2003. Pleistocene exchange networks as evidence for the evolution of language. Cambridge Archaeological Journal 13, 67-71.

McBrearty, S., 1981. Songhor: a Middle Stone Age Site in western Kenya. Quaternaria. Storia Naturale e Culturale del Quaternario Roma 23, 171-190.

McBrearty, S., 1988. The Sangoan-Lupemban and Middle Stone Age sequence at the Muguruk Site, Western Kenya. World Archaeology 19, 388-420.

McBrearty, S., Brooks, A.S., 2000. The revolution that wasn't: a new interpretation of the origins of modern human behaviour. Journal of Human Evolution 39, 453-563.

McCall, G.S., 2007. Behavioral ecological models of lithic technological change during the later Middle Stone Age of South Africa. Journal of Archaeological Science 34, 1738-1751.

Mehlman, M.J., 1989. Later quaternary archaeological sequences in northern Tanzania. Ph.D. dissertation, University of Illinois at Urbana-Champaign.

Meltzer, D.J., 1989. Was stone exchanged among eastern North American paleoindians? In: Ellis, C.J., Lothrop, J.C. (Eds.), Eastern Paleoindian Lithic Resource Use (Investigations in American Archaeology). Westview Press, Boulder, Colorado, pp. 11-39.

Merrick, H.V., Brown, F.H., 1984. Obsidian sources and patterns of source utilization in Kenya and northern Tanzania: some initial findings. African Archaeological Review 2, 129-152.

Merrick, H.V., Brown, F.H., Nash, W.P., 1994. Use and movement of obsidian in the Early and Middle Stone Ages of Kenya and northern Tanzania. In: Childs, S.T. (Ed.), Society, Culture, and Technology in Africa. MASCA, Philadelphia, pp. 29-44.

Migal, W., 2006. The macrolithic flint blades of the Neolithic times in Poland. In: Apel, J., Knutsson, K. (Eds.), Skilled Production and Social Reproduction. Societas Archaeologica Upsaliensis, Uppsala, pp. 387-398.

Milne, S.B., Hamilton, A., Fayek, M., 2009. Combining visual and geochemical analyses to source chert on Southern Baffin Island, Arctic Canada. Geoarchaeology 24, 429-449.

Minichillo, T., 2006. Raw material use and behavioral modernity: Howiesons Poort lithic foraging strategies. Journal of Human Evolution 50, 359-364. 
Monnier, G.F., McNulty, K.P., 2010. Questioning the link between stone tool standardization and behavioral modernity. In: Lycett, S., Chauhan, P. (Eds.), New Perspectives on Old Stones. Springer, New York, pp. 61-81.

Morgan, L.E., Renne, P.R., Taylor, R.E., WoldeGabriel, G., 2009. Archaeological age constraints from extrusion ages of obsidian: Examples from the Middle Awash, Ethiopia. Quaternary Geochronology 4, 193-203.

Moroni, B., Petrelli, M., 2005. Geochemical characterization of flint artifacts by inductively coupled plasma-mass spectrometry with laser sampling (LA-ICP-MS): results and prospects. Mediterranean Archaeology and Archaeometry 5, 49-62.

Murphy, M.L., 1999. Changing human behaviour: the contribution of the White Paintings Rock Shelter to an understanding of changing lithic reduction, raw material exchange and hunter-gatherer mobility in the interior regions of southern Africa during the Middle and Early Late Stone Age. Ph.D. Dissertation, Michigan State University.

Nash, D.J., Shaw, P.A., 1998. Silica and carbonate relationships in silcrete-calcrete intergrade duricrusts from the Kalahari of Botswana and Namibia. Journal of African Earth Sciences 27, $11-$ 25 .

Nash, D.J., McLaren, S.J., 2003. Kalahari valley calcretes: their nature, origins, and environmental significance. Quaternary International 111, 3-22.

Nash, D.J., Ullyott, J.S., 2007. Silcrete. In: Nash, D.J., McLaren, S.J. (Eds.), Geochemical Sediments and Landscapes. Blackwell, Oxford, pp. 95-143.

Nash, D.J., McLaren, S.J., Webb, J.A., 2004. Petrology, geochemistry and environmental significance of silcrete-calcrete intergrade duricrusts at Kang Pan and Tswaane, Central Kalahari, Botswana. Earth Surface Processes and Landforms 29, 1559-1586.

Nash, D.J., Coulson, S., Staurset, S., Ullyott, J.S., Babutsi, M., Hopkinson, L., Smith, M.P., $2013 a$. Provenancing of silcrete raw materials indicates long-distance transport to Tsodilo Hills, Botswana, during the Middle Stone Age. Journal of Human Evolution 64, 280-288.

Nash, D.J., Coulson, S., Staurset, S., Smith, M.P., Ullyott, J.S., 2013b. Provenancing silcrete in the Cape coastal zone: implications for Middle Stone Age research in South Africa. Journal of Human Evolution 65, 682-688.

Navazo, M., Colina, A., Domínguez-Bella, S., Benito-Calvo, A., 2008. Raw stone material supply for Upper Pleistocene settlements in Sierra de Atapuerca (Burgos, Spain): flint characterization using petrographic and geochemical techniques. Journal of Archaeological Science 35, 1961-1973.

Negash, A., Shackley, M.S., 2006. Geochemical provenance of obsidian artefacts from the MSA site of Porc Epic, Ethiopia. Archaeometry 48, 1-12.

Negash, A., Alene, M., Brown, F.H., Nash, B.P., Shackley, M.S., 2007. Geochemical sources for the terminal Pleistocene/early Holocene obsidian artifacts of the site of Beseka, central Ethiopia. Journal of Archaeological Science 34, 1205-1210.

Newman, J.R., 1994. The effects of distance on lithic material reduction technology. Journal of Field Archaeology 21, 491-501. 
Nugent, C., 1990. The Zambezi River: tectonism, climatic change and drainage evolution. Palaeogeography Palaeoclimatology Palaeoecology 78, 55-69.

Olofsson, A., Rodushkin, I., 2011. Provenancing flint artefacts with ICP-MS using REE signatures and $\mathrm{Pb}$ isotopes as discriminants: preliminary results of a case study from northern Sweden. Archaeometry 53, 1142-1170.

Parish, R.M., 2011. The application of visible/near-infrared reflectance (VNIR) spectroscopy to chert: A case study from the Dover Quarry sites, Tennessee. Geoarchaeology 26, 420-439.

Paton, R., 1994. Speaking through stones: A study from northern Australia. World Archaeology 26, $172-184$.

Pearce, E., 2014. Modelling mechanisms of social network maintenance in hunter-gatherers. Journal of Archaeological Science 50, 403-413.

Pearce, E., Moutsiou, T., 2014. Using obsidian transfer distances to explore social network maintenance in late Pleistocene hunter-gatherers. Journal of Anthropological Archaeology 36, 12 20.Phillips, S.C., Speakman, R.J., 2009. Initial source evaluation of archaeological obsidian from the Kuril Islands of the Russian Far East using portable XRF. Journal of Archaeological Science 36, $1256-1263$.

Pitblado, B.L., Cannon, M.B., Neff, H., Dehler, C.M., Nelson, S.T., 2013. LA-ICP-MS analysis of quartzite from the Upper Gunnison Basin, Colorado. Journal of Archaeological Science 40, 21962216.

Pleurdeau, D., Hovers, E., Assefa, Z., Asrat, A., Pearson, O., Bahain, J.J., Lam, Y.M., 2014. Cultural change or continuity in the late MSA/Early LSA of southeastern Ethiopia? The site of Goda Buticha, Dire Dawa area. Quaternary International 343, 117-135.

Porraz, G., Texier, P.-J., Rigaud, J.-P., Parkington, J., Poggenpoel, C., Roberts, D.L., 2008. Preliminary characterization of a Middle Stone Age lithic assemblage preceding the 'Classic' Howieson's Poort Complex at Diepkloof Rock Shelter, Western Cape Province, South Africa. Goodwin Series 10, 105-121.

Porraz, G., Texier, P.-J., Archer, W., Piboule, M., Rigaud, J.-P., Tribolo, C., 2013a. Technological successions in the Middle Stone Age sequence of Diepkloof Rock Shelter, Western Cape, South Africa. Journal of Archaeological Science 40, 3376-3400.

Porraz, G., Parkington, J.E., Rigaud, J.-P., Miller, C.E., Poggenpoel, C., Tribolo, C., Archer, W., Cartwright, C.R., Charrié-Duhaut, A., Dayet, L., Igreja, M., Mercier, N., Schmidt, P., Verna, C., Texier, P.-J., 2013b. The MSA sequence of Diepkloof and the history of southern African Late Pleistocene populations. Journal of Archaeological Science 40, 3542-3552.

Railsback, L.B., Brook, G.A., Chen, J., Kalin, R., Fleisher, C.J., 1994. Environmental controls on the petrology of a late Holocene speleothem from Botswana with annual layers of aragonite and calcite. Journal of Sedimentary Research. Section A, Sedimentary Petrology and Processes 64 A, $147-155$.

Railsback, L.B., Brook, G.A., Webster, J.W., 1999. Petrology and paleoenvironmental significance of detrital sand and silt in a stalagmite from Drotsky's Cave, Botswana. Physical Geography 20, $331-347$. 
Rensink, E., Kolen, J., Spieksma, A., 1991. Patterns of raw material distribution in the Upper Pleistocene of northwestern and central Europe. In: Montet-White, A., Holen, S. (Eds.), Raw Material Economies among Prehistoric Hunter-Gatherers. University of Kansas, Lawrence, pp. $142-159$.

Robbins, L.H., Murphy, M.L., 1998. The Early and Middle Stone Age. In: Lane, P., Reid, A., Segobye, A. (Eds.), Ditswa Mmung. The Archaeology of Botswana. The Botswana Society and Pula Press, Gaborone, pp. 50-64.

Robbins, L.H., Murphy, M.L., 2011. An Overview of the Later and Middle Stone Age at Tsodilo Hills. Botswana Notes and Records 43, 130-139.

Robbins, L.H., Murphy, M.L., Campbell, A.C., Brook, G.A., 1996a. Excavations at the Tsodilo Hills Rhino Cave. Botswana Notes and Records 28, 23-45.

Robbins, L.H., Murphy, M.L., Stevens, N.J., Brook, G.A., Ivester, A.H., Haberyan, K.A., Klein, R.G., Milo, R., Stewart, K.M., Matthiesen, D.G., Winkler, A.J., 1996b. Paleoenvironment and archaeology of Drotsky's Cave: Western Kalahari Desert, Botswana. Journal of Archaeological Science 23, 7-22.

Robbins, L.H., Murphy, M.L., Brook, G.A., Ivester, A.H., Campbell, A.C., Klein, R.G., Milo, R.G., Stewart, K.M., Downey, W.S., Stevens, N.J., 2000a. Archaeology, palaeoenvironment, and chronology of the Tsodilo Hills White Paintings Rock Shelter, Northwest Kalahari Desert, Botswana. Journal of Archaeological Science 27, 1085-1113.

Robbins, L.H., Brook, G.A., Murphy, M.L., Campbell, A.C., Melear, N., Downey, W.S., $2000 b$. Late Quaternary archaeological and palaeoenvironmental data from sediments at Rhino Cave, Tsodilo Hills, Botswana. Southern African Field Archaeology 9, 17-31.

Roebroeks, W., Kolen, J., Rensink, E., 1988. Planning depth, anticipation and the organization of Middle Palaeolithic technology: The "Archaic Natives" meet Eve's descendants. Helinium 28, 1734.

Ross, A., Anderson, B., Campbell, C., 2003. Gunumbah: Archaeological and Aboriginal meanings at a quarry site on Moreton Island, southeast Queensland. Australian Archaeology 57, 75-81.

Roth, B.J., 2000. Obsidian Source Characterization and hunter-gatherer mobility: An example from the Tucson Basin. Journal of Archaeological Science 27, 305-314.

Schmidt, P., Porraz, G., Slodczyk, A., Bellot-Gurlet, L., Archer, W., Miller, C.E., 2013. Heat treatment in the South African Middle Stone Age: temperature induced transformations of silcrete and their technological implications. Journal of Archaeological Science 40, 3519-3531.

Schmidt, P., Porraz, G., Bellot-Gurlet, L., February, E., Ligouis, B., Paris, C., Texier, P.-J., Parkington, J.E., Miller, C.E., Nickel, K.G., Conard, N.J., 2015. A previously undescribed organic residue sheds light on heat treatment in the Middle Stone Age. Journal of Human Evolution 85, 2234.

Shackley, M.S., 1987. Comment on "Tomato Springs: The identification of a jasper trade and production center in Southern California". American Antiquity 52, 616-623.

Shackley, M.S., 1995. Sources of archaeological obsidian in the greater American southwest: An update and quantitative analysis. American Antiquity 60, 531-551. 
Shaw, P.A., Cooke, H.J., 1986. Geomorphic evidence for the Late Quaternary palaeoclimates of the Middle Kalahari of Northern Botswana. Catena 13, 349-359.

Shaw, P.A., Nash, D.J., 1998. Dual mechanisms for the formation of fluvial silcretes in the distal reaches of the Okavango Delta Fan, Botswana. Earth Surface Processes and Landforms 23, 705714.

Shaw, P.A., Thomas, D.S.G., 1988. Lake Caprivi: a Late Quaternary link between the Zambezi and middle Kalahari drainage systems. Zeitschrift für Geomorphologie 32, 329-337.

Shaw, P.A., Thomas, D.S.G., Nash, D.J., 1992. Late Quaternary fluvial activity in the dry valleys (mekgacha) of the Middle and Southern Kalahari, Southern Africa. Journal of Quaternary Science 7, 273-281.

Sholts, S.B., Stanford, D.J., Flores, L.M., Wärmländer, S.K., 2012. Flake scar patterns of Clovis points analyzed with a new digital morphometrics approach: evidence for direct transmission of technological knowledge across early North America. Journal of Archaeological Science 39, 3018 3026.

Shott, M., 1986. Technological Organization and Settlement Mobility—an Ethnographic Examination. Journal of Anthropological Research 42, 15-51.

Smith, G.M., 2010. Footprints across the Black Rock: Temporal variability in prehistoric foraging territories and toolstone procurement strategies in the Western Great Basin. American Antiquity 75, $865-885$.

Smith, G.M., Kielhofer, J., 2011. Through the High Rock and beyond: placing the Last Supper Cave and Parman Paleoindian lithic assemblages into a regional context. Journal of Archaeological Science 38, 3568-3576.

Speer, C.A., 2014. LA-ICP-MS analysis of Clovis period projectile points from the Gault Site. Journal of Archaeological Science 52, 1-11.

Speth, J.D., Newlander, K., White, A.A., Lemke, A.K., Anderson, L.E., 2013. Early Paleoindian big-game hunting in North America: Provisioning or politics? Quaternary International 285, 111 139.

Staurset, S., 2014. Lithic technology and prehistoric behaviour patterns in the Middle Stone Age of Tsodilo Hills, Botswana. Ph.D. Dissertation, University of Oslo.

Staurset, S., Coulson, S., 2014. Sub-surface movement of stone artefacts at White Paintings Shelter, Tsodilo Hills, Botswana: Implications for the Middle Stone Age chronology of central southern Africa. Journal of Human Evolution 75, 153-165.

Stiner, M.C., 2013. An unshakable Middle Paleolithic? Trends versus conservatism in the predatory niche and their social ramifications. Current Anthropology 54, S288-S304.

Stout, D., 2002. Skill and cognition in stone tool production: An ethnographic case study from Irian Jaya. Current Anthropology 43, 693-722.

Summerfield, M.A., 1983. Silcrete. In: Goudie, A.S., Pye, K. (Eds.), Chemical Sediments and Geomorphology. Academic Press, London, pp. 59-91.

Tabachnick, B.G., Fidell, L.S., 2001. Using multivariate statistics. Pearson, New York. 
Taçon, P.S.C., 1991. The power of stone: symbolic aspects of stone use and tool development in western Arnhem Land, Australia. Antiquity 65, 192-207.

Tankersley, K.B., 1991. A geoarchaeological investigation of distribution and exchange in the raw material economies of Clovis groups in eastern North America. In: Montet-White, A., Holen, S. (Eds.), Raw Material Economies among Prehistoric Hunter-Gatherers. University of Kansas, Lawrence, pp. 285-303.

Thacker, P.T., Ellwood, B.B., 2002. The magnetic susceptibility of cherts: archaeological and geochemical implications of source variation. Geoarchaeology 17, 465-482.

Thomas, D.S.G., Shaw, P.A., 1991. The Kalahari Environment. Cambridge University Press, Cambridge.

Thomas, D.S.G., Shaw, P.A., 1992. The Zambezi River: tectonism, climatic change and drainage evolution - is there really evidence for a catastrophic flood? A discussion. Palaeogeography Palaeoclimatology Palaeoecology 91, 175-178.

Tibbett, K., 2006. When east is northwest: Expanding the archaeological boundary for Leilira blade production. Australian Archaeology 62, 26-30.

Tykot, R.H., 2003. Determining the source of lithic artifacts and reconstructing trade in the ancient world. In: Kardulias, P.N., Yerkes, R.W. (Eds.), Written in Stone: The Multiple Dimensions of Lithic Analysis. Lexington Books, Lanham, pp. 59-85.

Vogel, N., Nomade, S., Negash, A., Renne, P.R., 2006. Forensic 40Ar/39Ar dating: a provenance study of Middle Stone Age obsidian artifacts from Ethiopia. Journal of Archaeological Science 33, 1749-1765.

Walker, N., 2008. Through the crystal ball: Making sense of spheroids in the Middle Stone Age. South African Archaeological Bulletin 63, 12-17.

Walker, N., 2010. Cups and saucers: a preliminary investigation of the rock carvings of Tsodilo, Botswana. In: Blundell, G., Chippindale, C., Smith, B. (Eds.), Seeing and Knowing: understanding rock art with and without ethnography. Witwatersrand University Press, Johannesburg, pp. 55-72.

Wallace, I.J., Shea, J.J., 2006. Mobility patterns and core technologies in the Middle Paleolithic of the Levant. Journal of Archaeological Science 33, 1293-1309.

Wayland, E.J., 1944. Drodsky's cave. Geographical Journal 103, 230-233.

Whallon, R., 2006. Social networks and information: Non-“utilitarian" mobility among huntergatherers. Journal of Anthropological Archaeology 25, 259-270.

White, J.P., Thomas, D.H., 1972. What mean these stones? Ethnotaxonomic models and archaeological interpretations in the New Guinea Highlands. In: Clarke, D.L. (Ed.), Models in archaeology. Methuen Publishing Ltd, pp. 275-308.

White, K., Eckardt, F., 2006. Geochemical mapping of carbonate sediments in the Makgadikgadi basin, Botswana using moderate resolution remote sensing data. Earth Surface Processes and Landforms 31, 665-681.

Wilkins, J., 2010. Style, symboling, and interaction in Middle Stone Age societies. Vis-á-Vis: Explorations in Anthropology 10, 102-125. 
Wilson, L., 2007. Understanding prehistoric lithic raw material selection: application of a gravity model. Journal of Archaeological Method and Theory 14, 388-411.

Wurz, S., 1999. The Howiesons Poort backed artefacts from Klasies River: an argument for symbolic behaviour. South African Archaeological Bulletin 54, 38-50.

Wurz, S., 2010. Middle Stone Age stone tools from Klasies River main site and symbolic cognition. In: Nowell, A., Davidson, I. (Eds.), The cutting edge: stone tools and the evolution of cognition. Colorado University Press, Boulder, Colorado, pp. 135-158. 


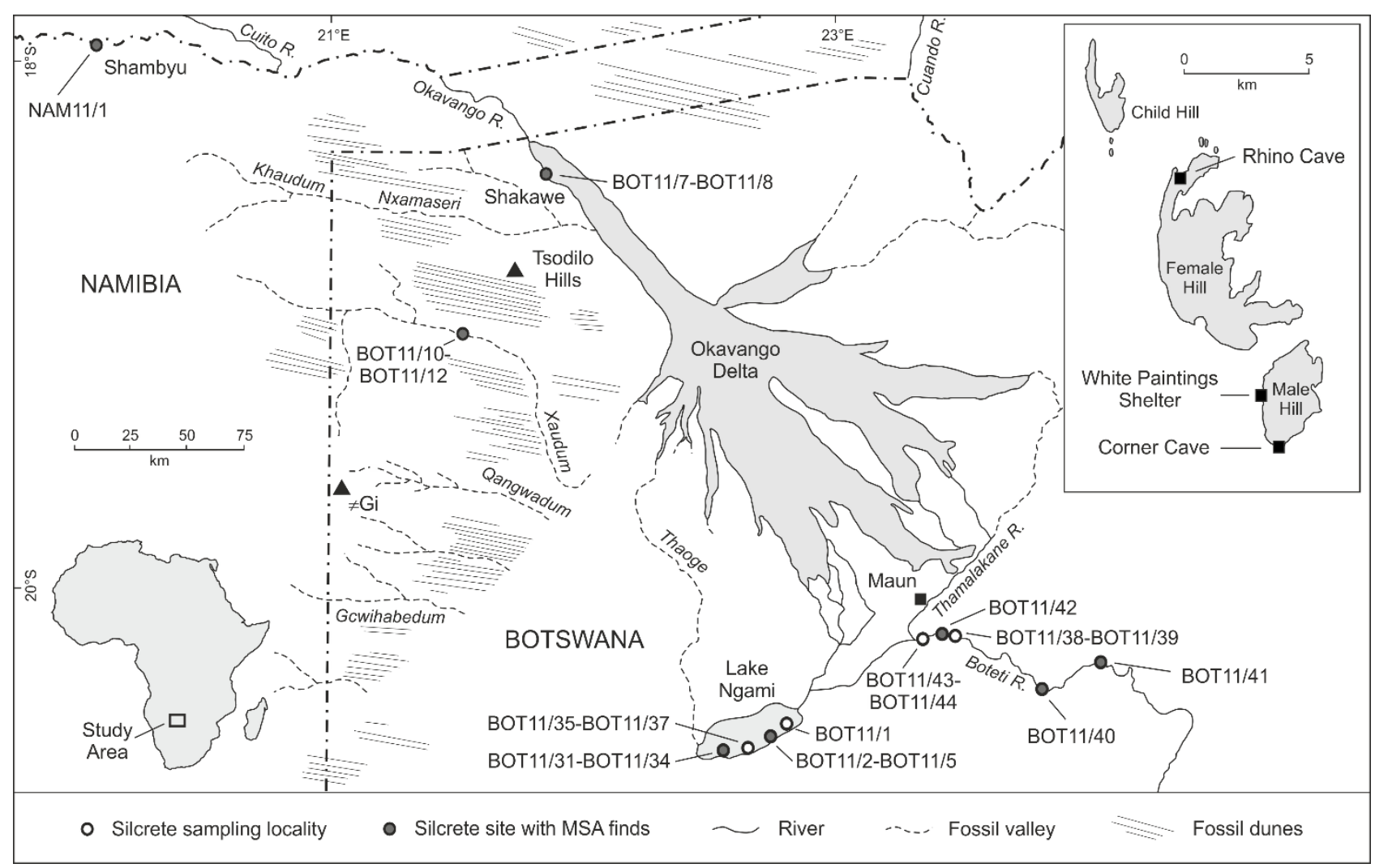

Figure 1. Map of the study area, showing the location of Rhino Cave, Corner Cave, and White Paintings Shelter within the Tsodilo Hills (see inset) and $\neq \mathrm{Gi}$, near the Namibian border. Black circles with no fill indicate sites where silcrete raw material samples used for geochemical and petrological analysis were collected. Infilled black circles indicate sites where surface diagnostic Middle Stone Age artefacts were identified during fieldwork. 

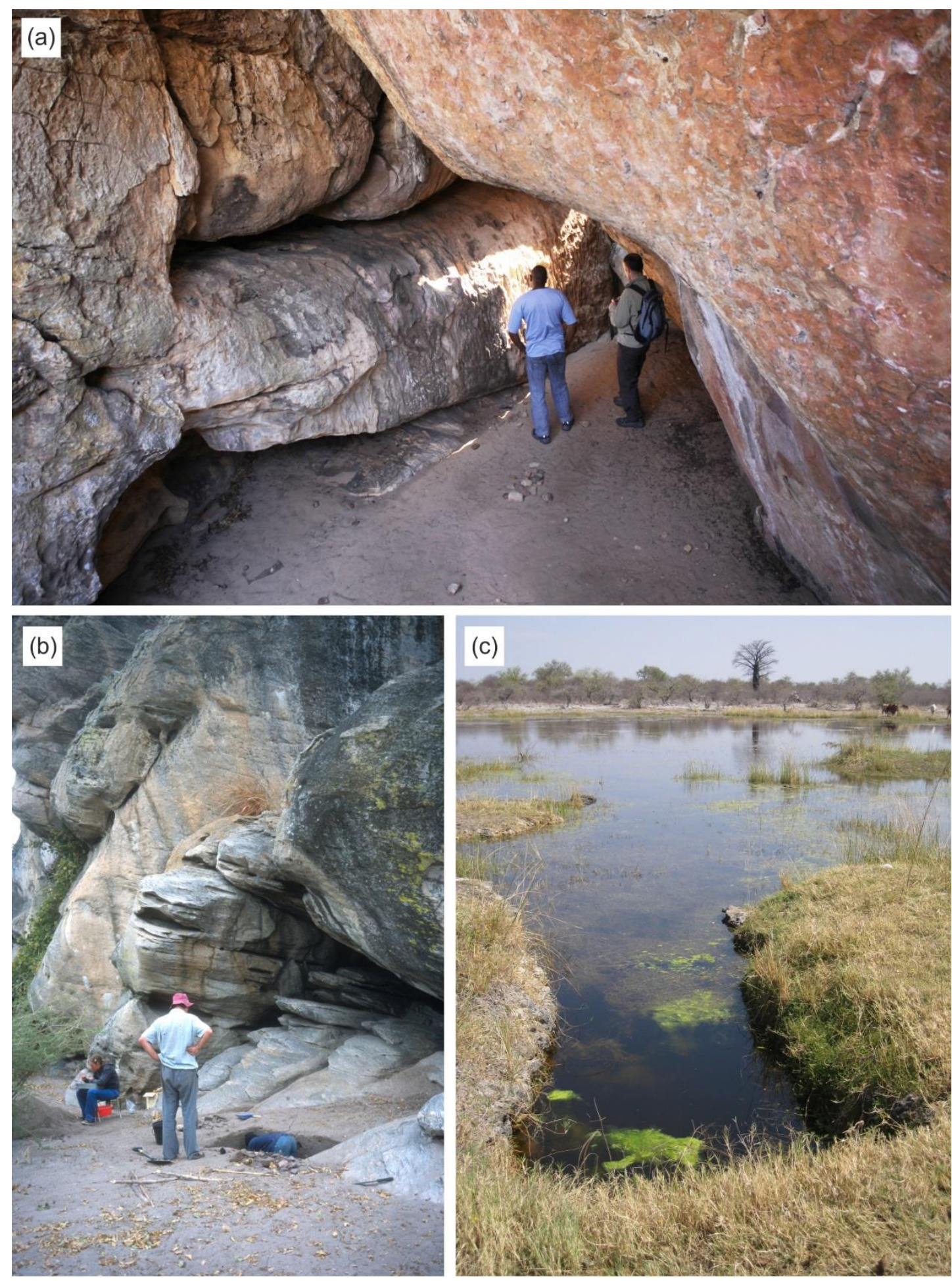

Figure 2. The three sites forming the focus of this investigation: (a) Rhino Cave, (b) Corner Cave, and (c) fGi. Photograph (a) taken by Trevor Thomas, (b) Sheila Coulson, and (c) David Nash. 
(a) Rhino Cave

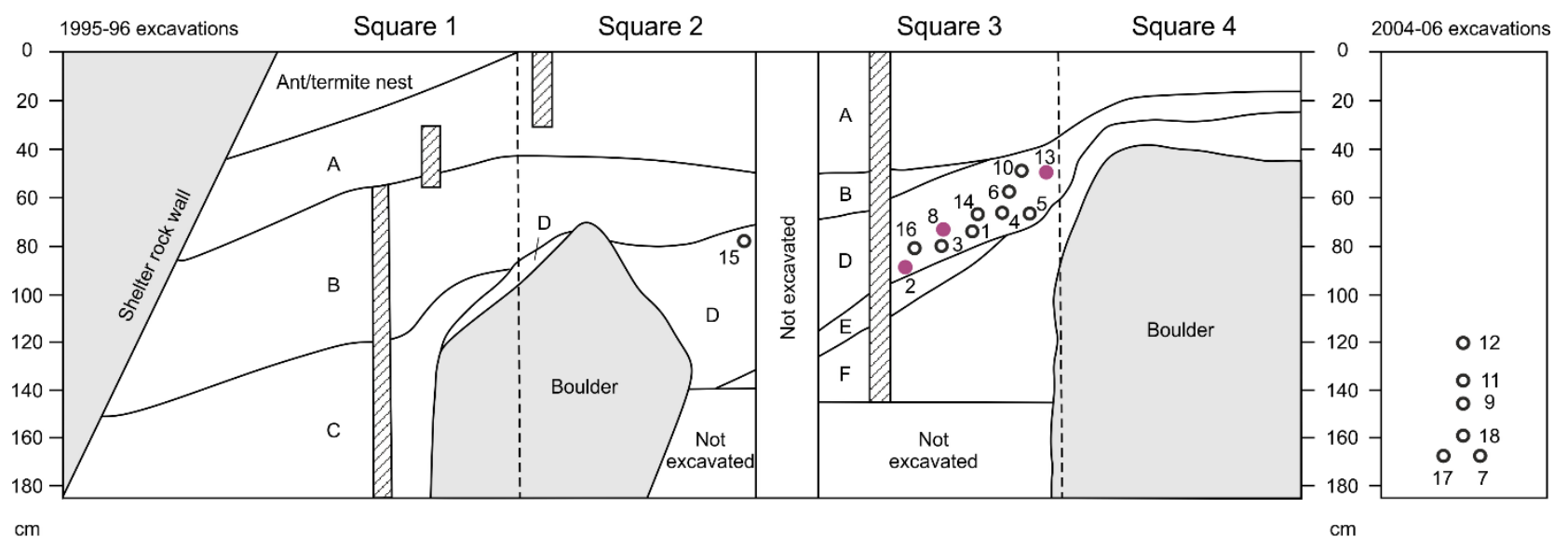

(b) Corner Cave

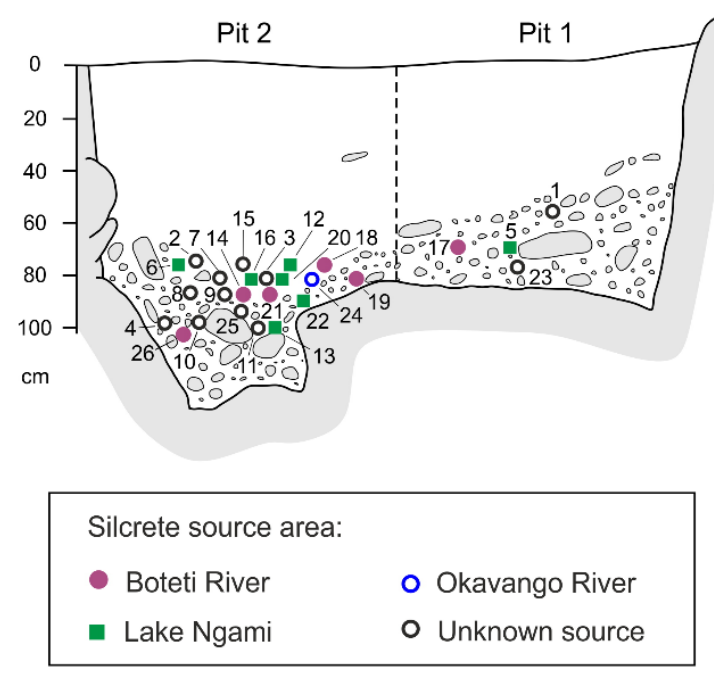

(c) $\neq \mathrm{Gi}$

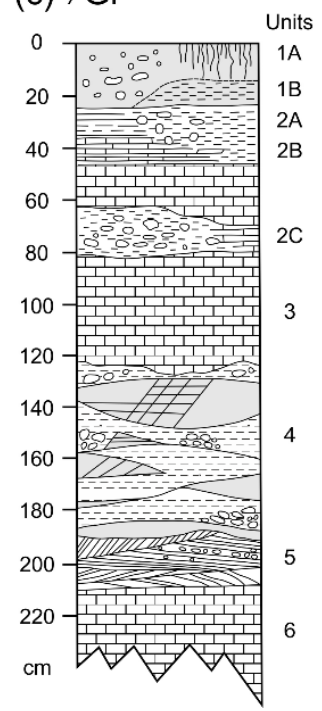

Figure 3. Stratigraphic cross-sections of the investigated sites. (a) Archaeological sequence from the 19951996 (adapted from Robbins et al., 2000b with permission from Elsevier) and 2004-2006 (from information in Coulson et al., 2011) excavations at Rhino Cave. (b) North wall of Corner Cave (after Nick Walker, excavation notes). (c) Archaeological sequence from $\neq$ Gi (adapted from Helgren and Brooks 1983, with permission from Elsevier). The approximate stratigraphic position of silcrete manufacturing waste flakes from Rhino Cave and Corner Cave analysed during this study are shown in (a) and (b) respectively. All samples from $\neq$ Gi were taken from units 4 and 5 . 


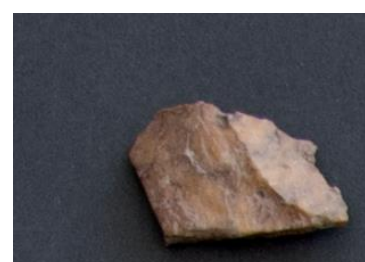

1

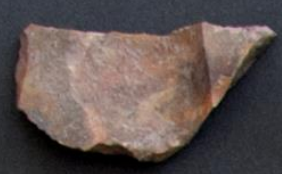

6
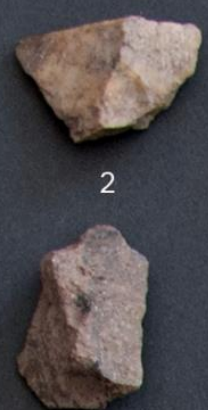

7

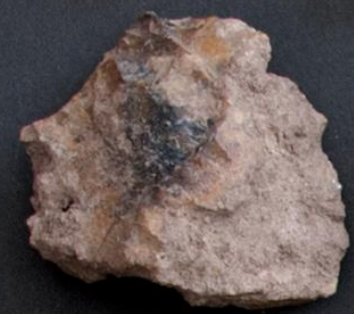

12

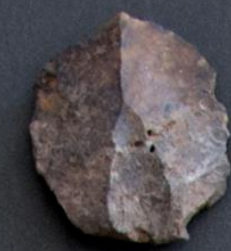

3

8

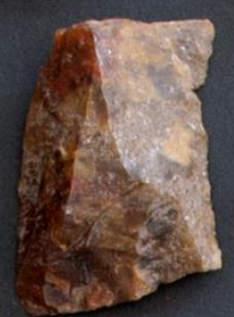

13
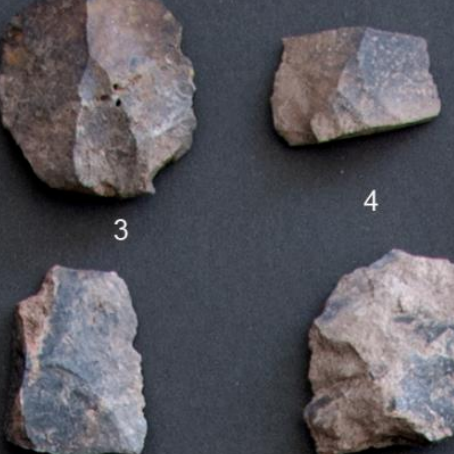

4

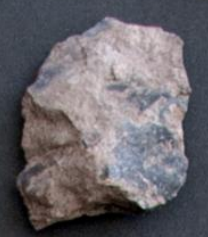

9

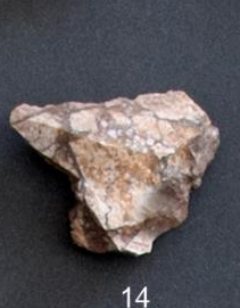

14
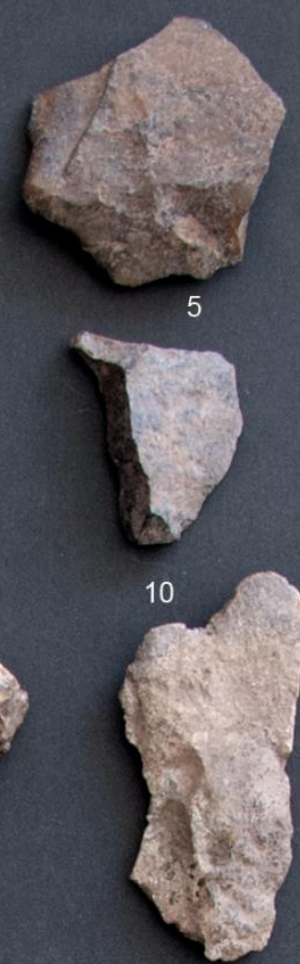

15

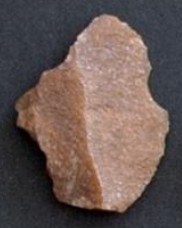

18

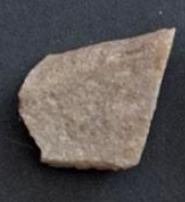

19

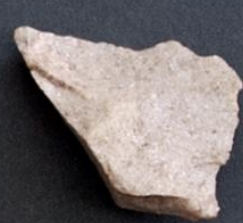

20

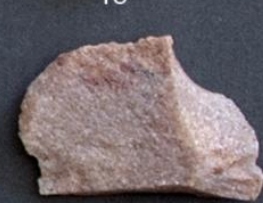

21

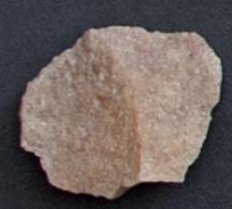

22

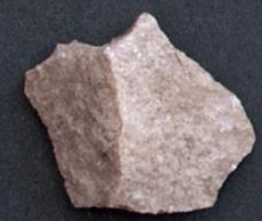

23

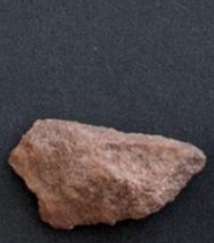

24

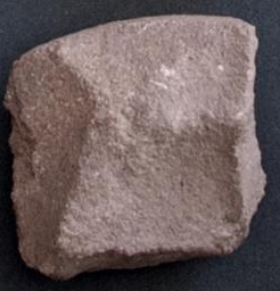

25

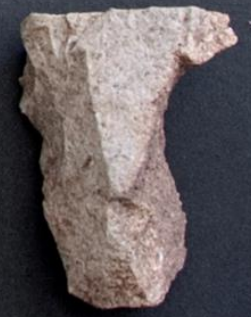

26

Figure 4. The 26 silcrete manufacturing waste flakes from the Middle Stone Age layers of Corner Cave, Tsodilo Hills, selected for geochemical analysis. Details for each waste flake are given in Table 2. Photographed in natural light by Sheila Coulson. 


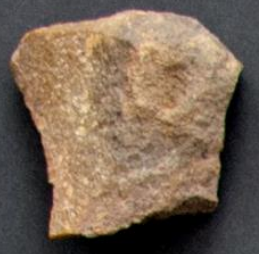

1

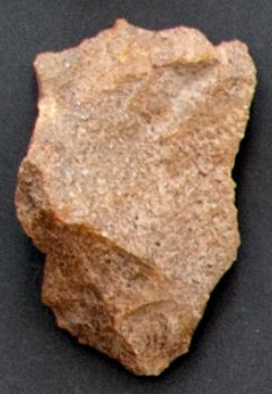

6

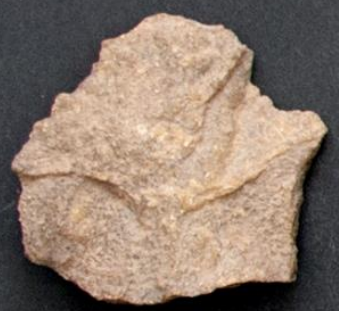

11

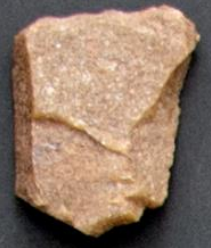

2
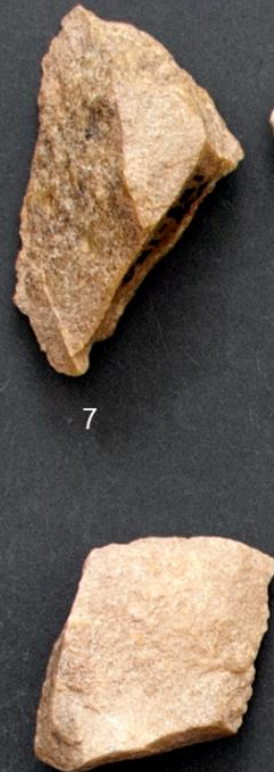

12

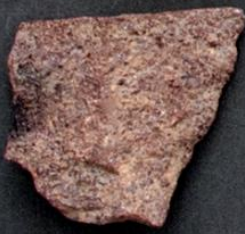

16

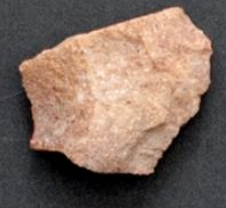

13

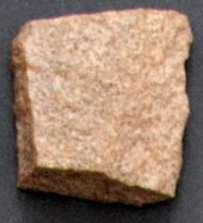

3

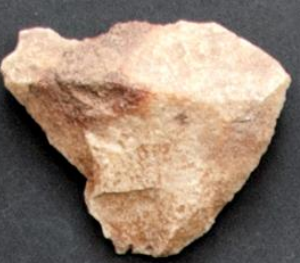

8

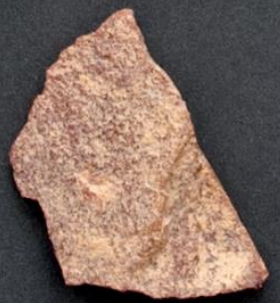

17

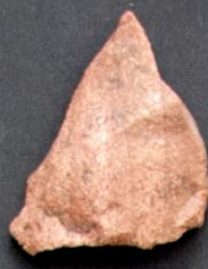

4

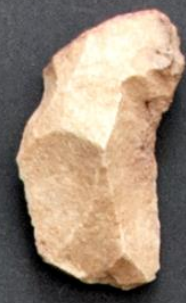

9

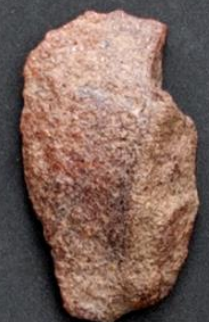

14

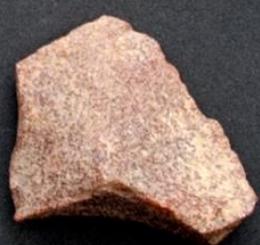

18

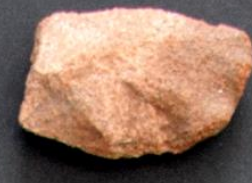

5

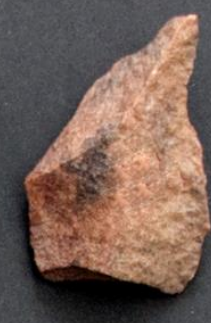

10

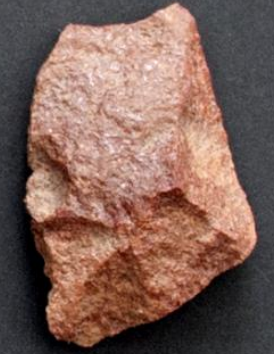

15

Figure 5. The 18 silcrete manufacturing waste flakes from the Middle Stone Age layers of Rhino Cave, Tsodilo Hills, selected for geochemical analysis. Details for each waste flake are given in Table 3. Photographed in natural light by Sheila Coulson. 


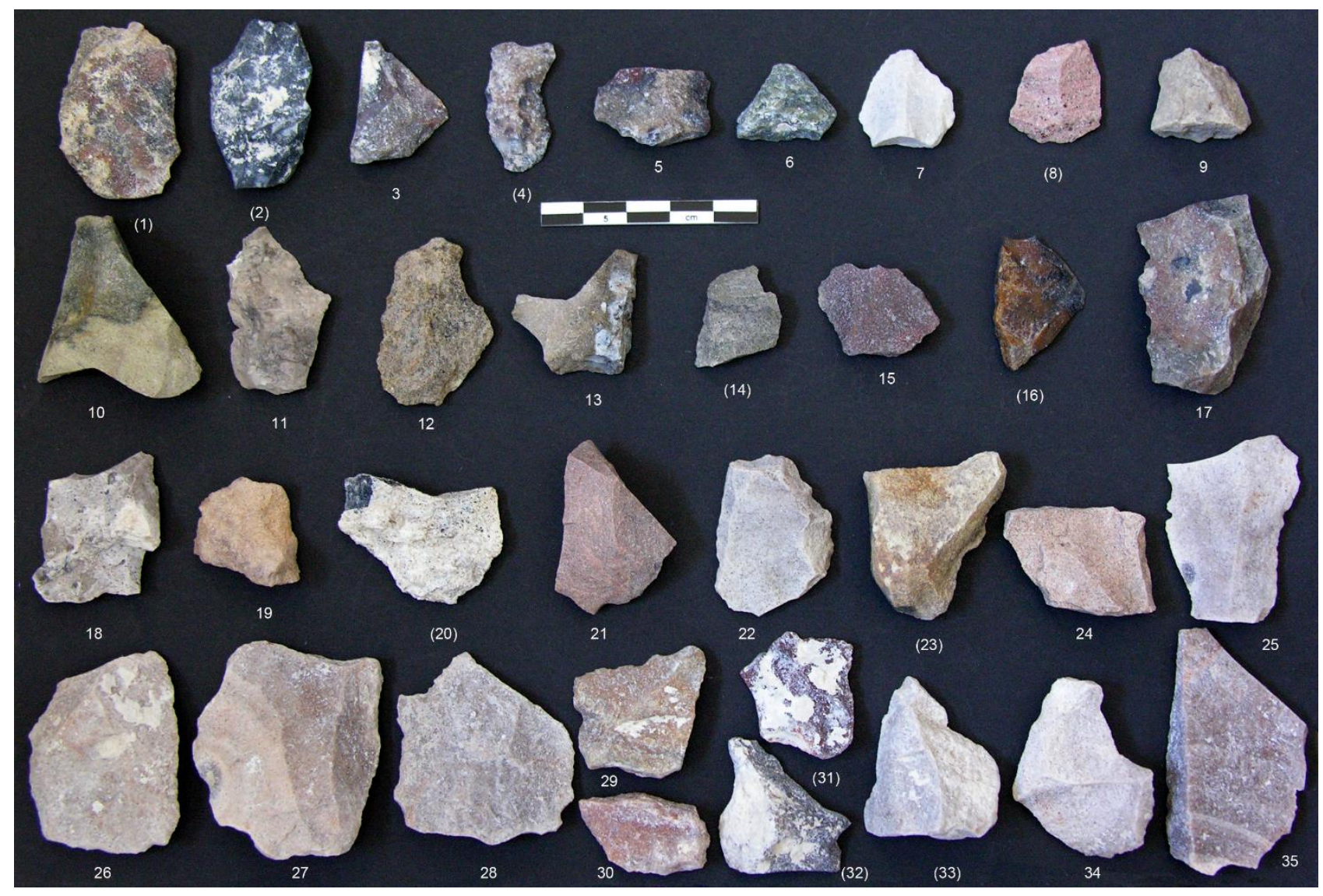

Figure 6. The 35 silcrete manufacturing waste flakes from the Middle Stone Age layers of $\neq$ Gi initially selected for geochemical analysis. Of these, 24 were found suitable for analysis. Samples not used are indicated in brackets. Details of the selected waste flake are given in Table 4. Photographed in natural light by Sheila Coulson. 
(a) Corner Cave

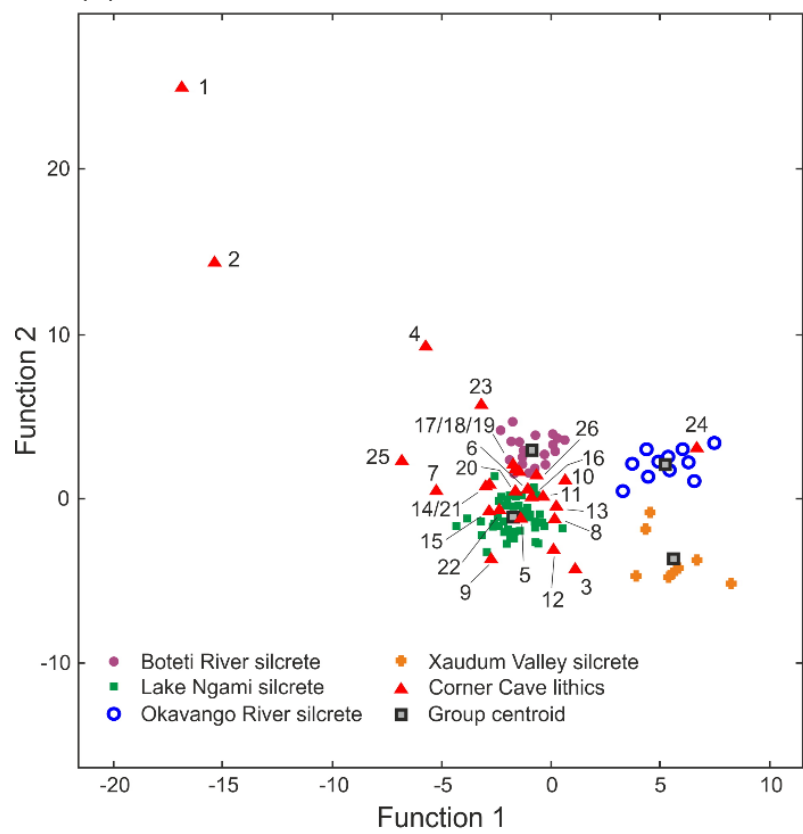

(c) $\neq \mathrm{Gi}$

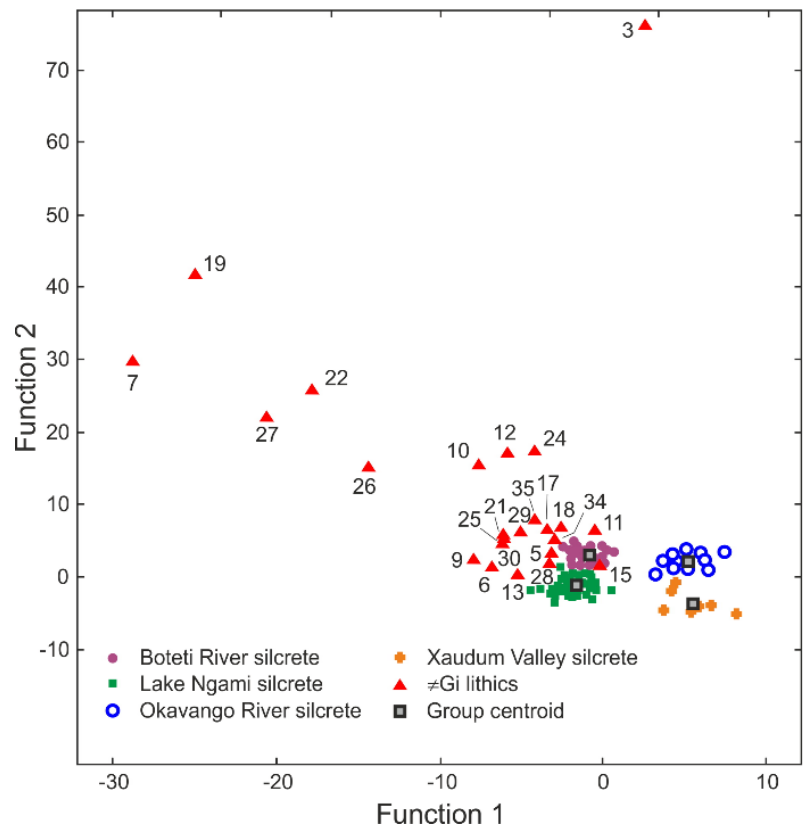

(b) Rhino Cave

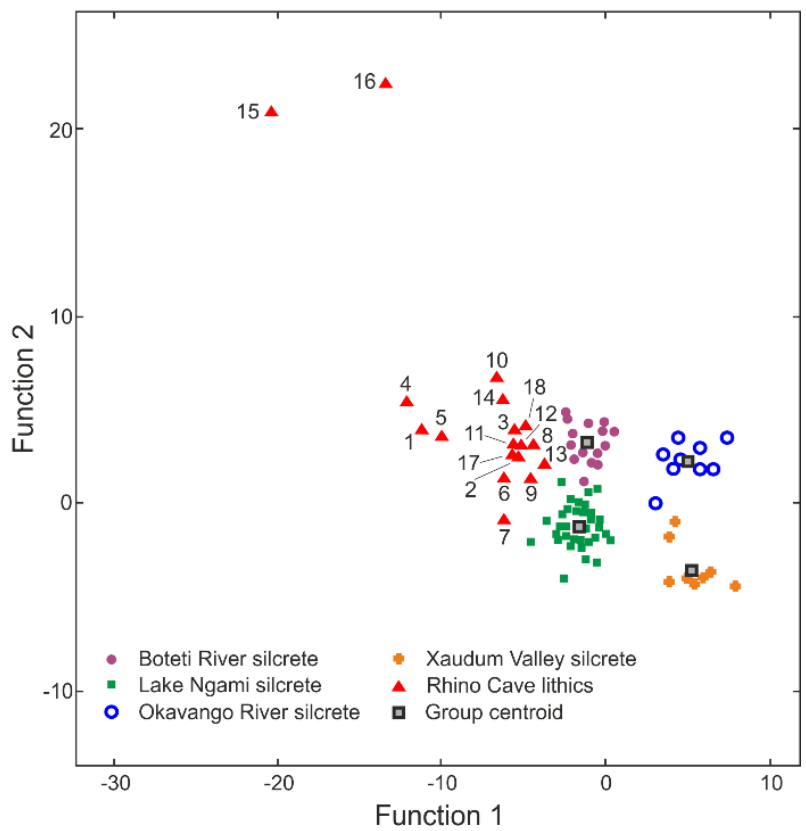

(d) White Paintings Shelter

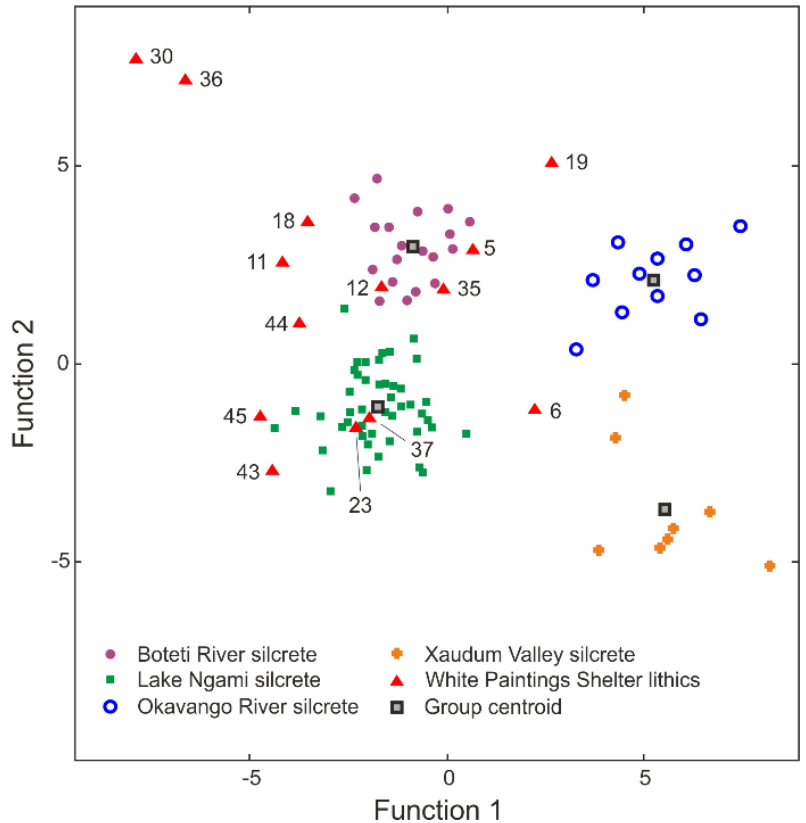

Figure 7. Results of canonical discriminant analysis of geochemical data from (a) Corner Cave, (b) Rhino Cave, and (c) $\neq \mathrm{Gi}$, each showing the first two discriminant functions from the respective analysis. Also shown is the equivalent plot for (d) White Paintings Shelter, published previously in Nash et al. (2013a). The silcrete raw material samples from the Boteti River, Lake Ngami, Okavango River, and Xaudum Valley form four discrete groupings on each of the discriminant plots. The positions of silcrete manufacturing waste flakes from each of the four archaeological sites are shown in relation to these groups. Note that the plots are two-dimensional representations of three-dimension datasets and should not simply be interpreted visuallysee text for a discussion. 


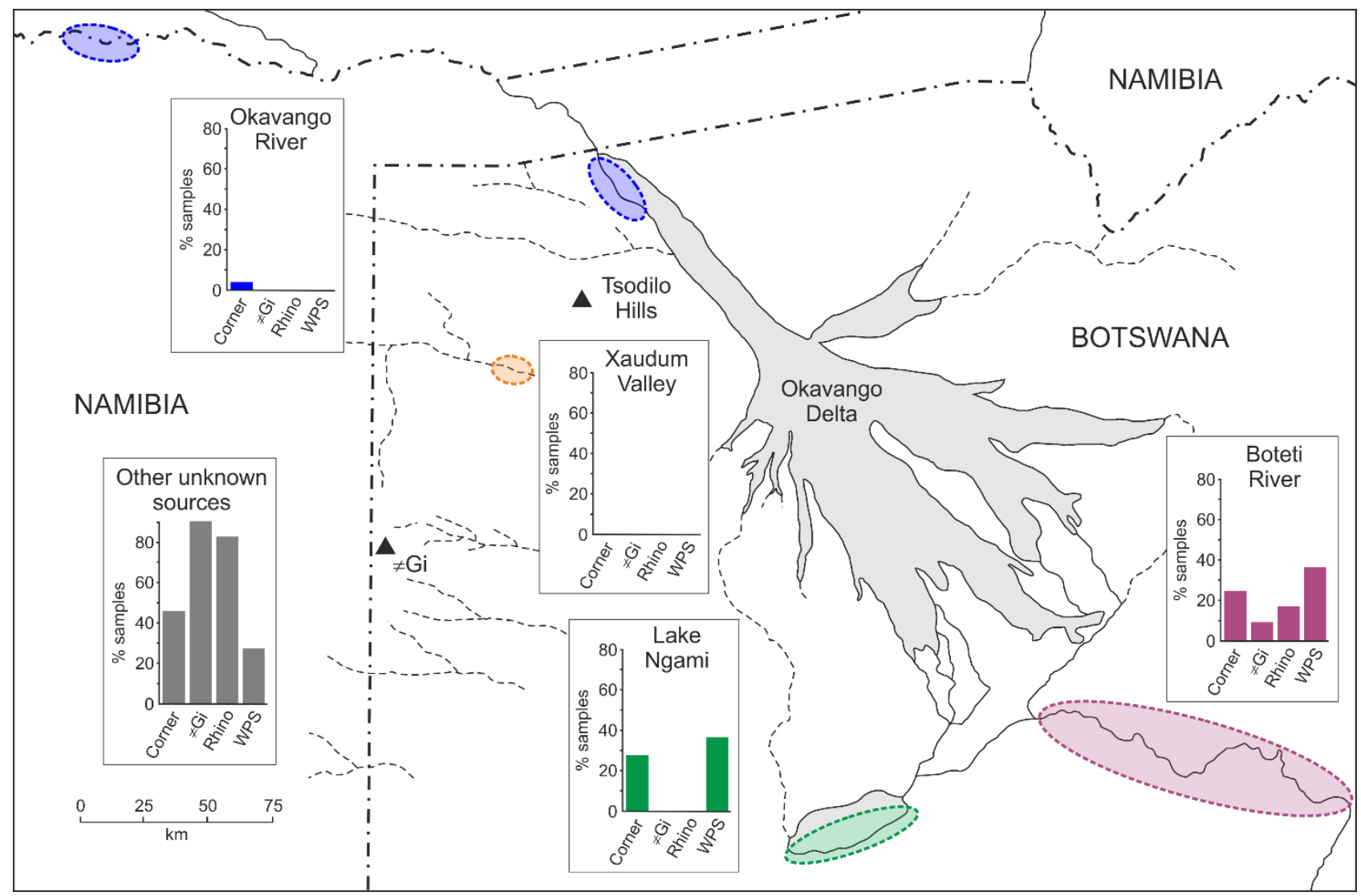

Figure 8. Proportions of silcrete artefacts from Rhino Cave, $\neq \mathrm{Gi}$, Corner Cave, and White Paintings Shelter sourced at 99\% statistical confidence from the Boteti River, Lake Ngami, the Okavango River, and Xaudum Valley. The percentages of artefacts at each archaeological site that were transported from unknown locations are also shown. Coloured ellipses represent the main areas of silcrete outcrop, with colours matching those of the individual bar charts. 

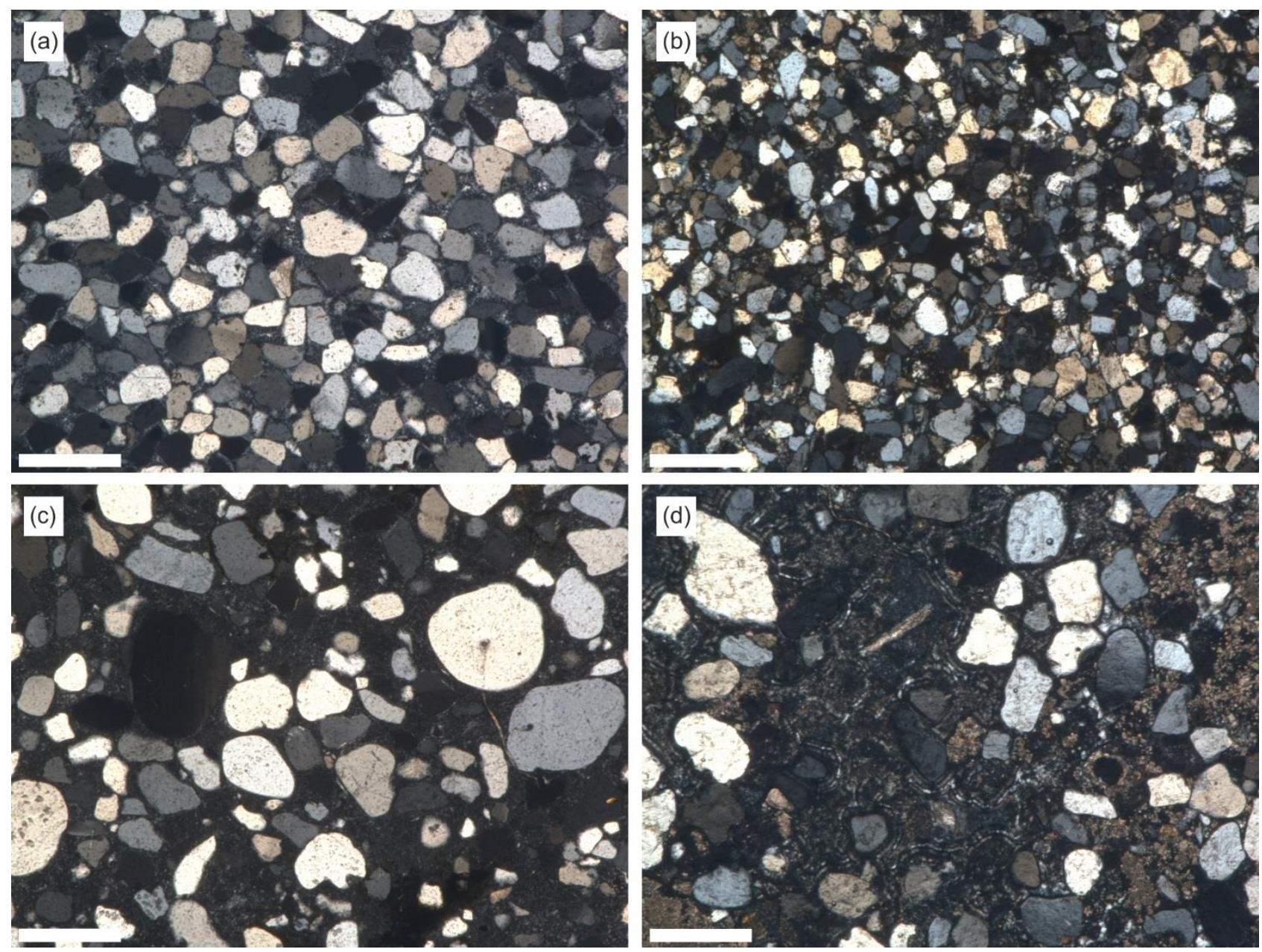

Figure 9. Photomicrographs of silcrete from the four geochemical domains identified by Nash et al. (2013a): (a) Sample BOT11/38/2 from the Boteti River, (b) Sample BOT11/4/2 from Lake Ngami, (c) Sample BOT11/7/4 from the Okavango River at Shakawe, and (d) Sample BOT11/11/3 from the Xaudum Valley. Samples from the Boteti, Lake Ngami, and the Okavango River consist of rounded to sub-angular quartz grains cemented by microquartz with minor chalcedony. Samples from the Xaudum Valley contain rock fragments in addition to quartz, have a higher proportion of chalcedony, and some areas of calcite cement. All samples are photographed in cross-polarised light. Scale bar on all images is $0.5 \mathrm{~mm}$. Photographs by David Nash. 

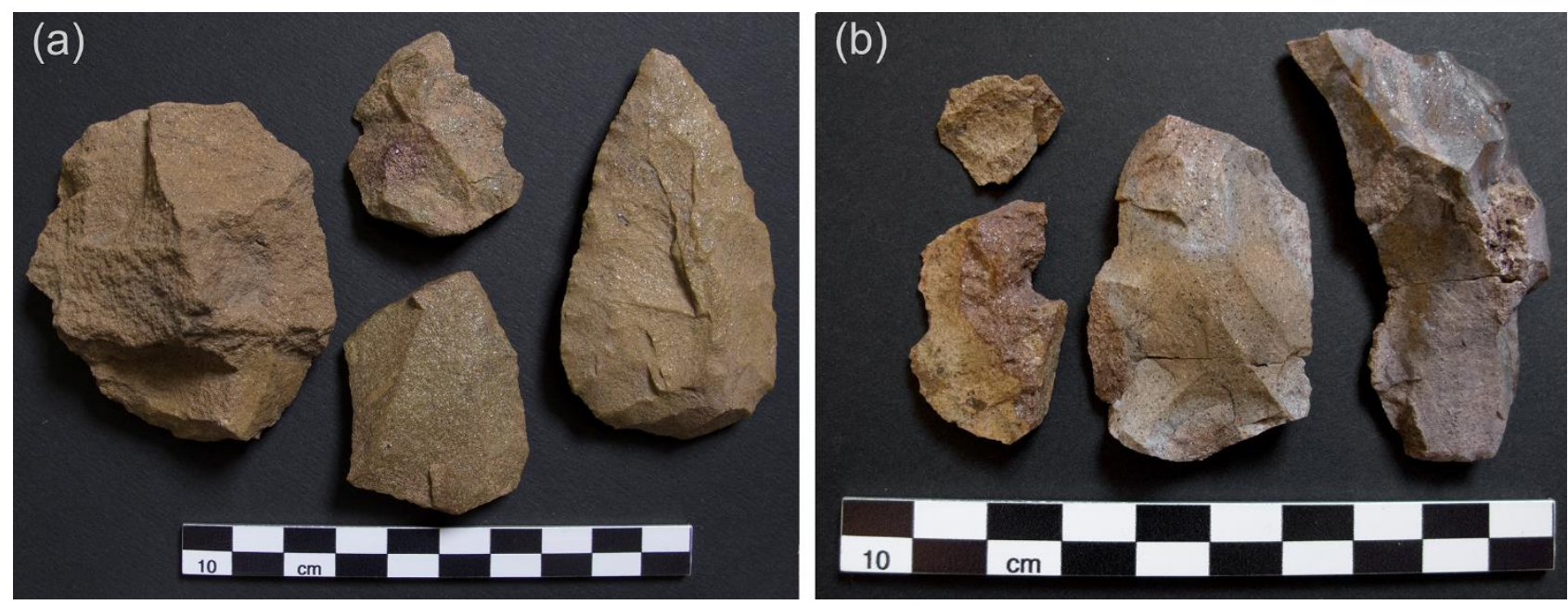

Figure 10. Examples of imported silcrete used in Middle Stone Age tool production at Tsodilo Hills: (a) Flake with preserved weathered nodule surface, blanks from prepared cores, and a bifacial point from Rhino Cave. All artefacts belong to material group 4B (described in SOM Table S2), one sample of which is geochemically provenanced to the Boteti River (see Table 2). (b) Partially corticated outer flakes and a blank from Corner Cave. All artefacts belong to material group 3D (described in SOM Table S1), one sample of which is geochemically provenanced to Lake Ngami (see Table 3). Photographed in natural light by Sigrid Staurset. 


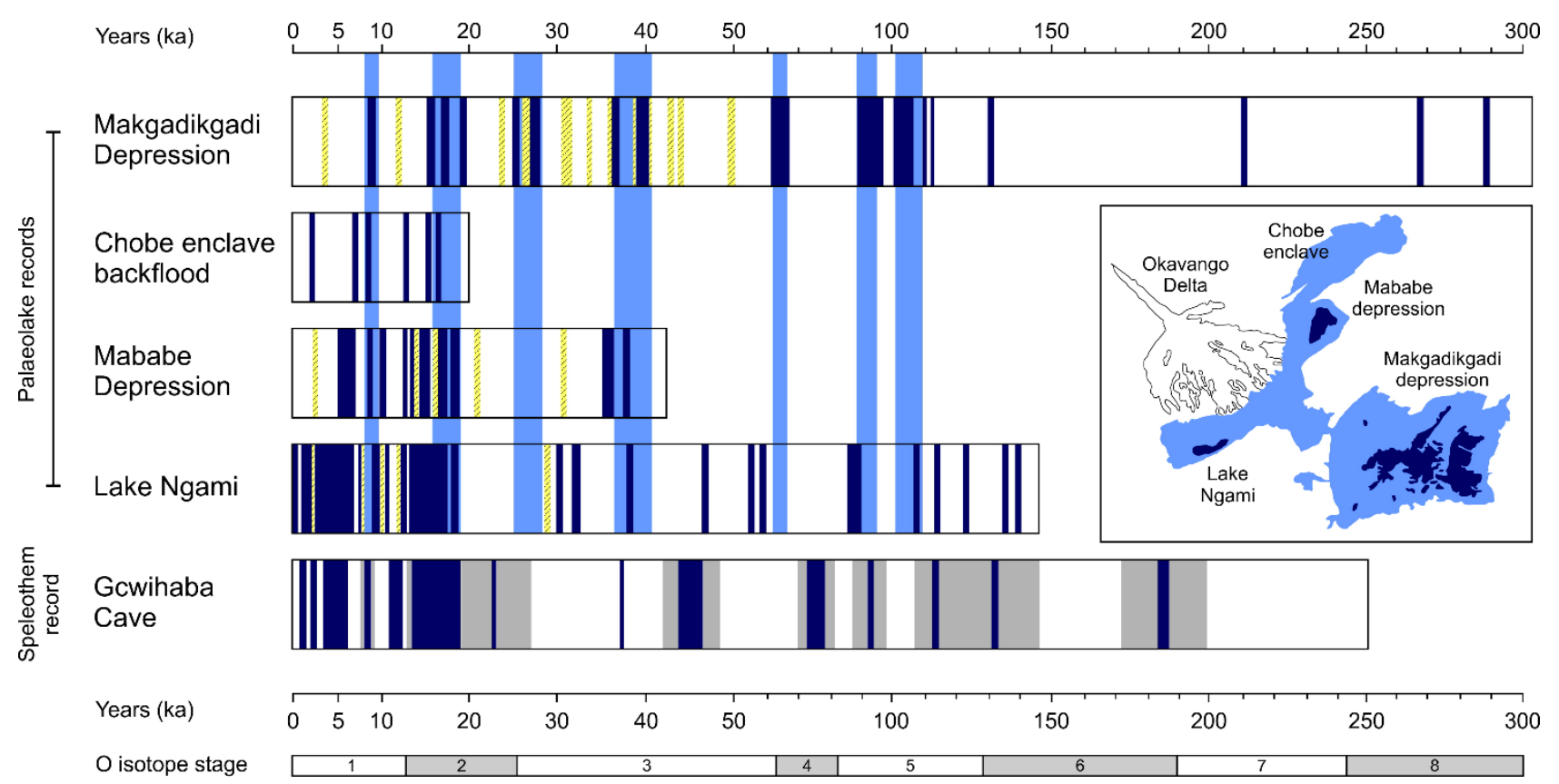

Figure 11. Key palaeoenvironmental records for northern Botswana that span the Middle Stone Age. Palaeolake records include lake high-stand chronologies for the four Palaeolake Makgadikgadi sub-basins: Makgadikgadi Depression, Chobe enclave backfloods, Mababe Depression, and Lake Ngami. Dark blue bars within rows indicate dated lake shoreline ridge accumulation periods. Inferred palaeo-mega-lake phases affecting all four sub-basins are indicated by light blue vertical bars. Yellow hatched bars indicate dated periods of calcrete formation within the basins and shorelines (see Burrough et al., 2009b for data and discussion). Also shown is a composite speleothem record from Gcwihaba (Drotsky's) Cave. Dark blue bars within rows indicate inferred 'wet phases' in northwest Botswana, with grey bars representing age errors. The inset map (after Burrough et al., 2009a) shows the locations of present-day sumps within the OkavangoMakgadikgadi system (dark blue) and the area likely to have been inundated during palaeo-mega-lake phases (light blue). Data for the Palaeolake Makgadikgadi sub-basins are taken from Burrough et al. (2007, 2009a), Burrough and Thomas (2008), and Burrough and Thomas (2008). The speleothem record for Gcwihaba Cave is adapted from Burrough et al. (2007) and based on data in Wayland (1944), Cooke (1975, 1984), Cooke and Verhagen (1977), Shaw and Cooke (1986), Burney et al. (1994), Railsback et al. (1994, 1999), Brook et al. (1996, 1997, 1998), and Robbins et al. (1996b). 


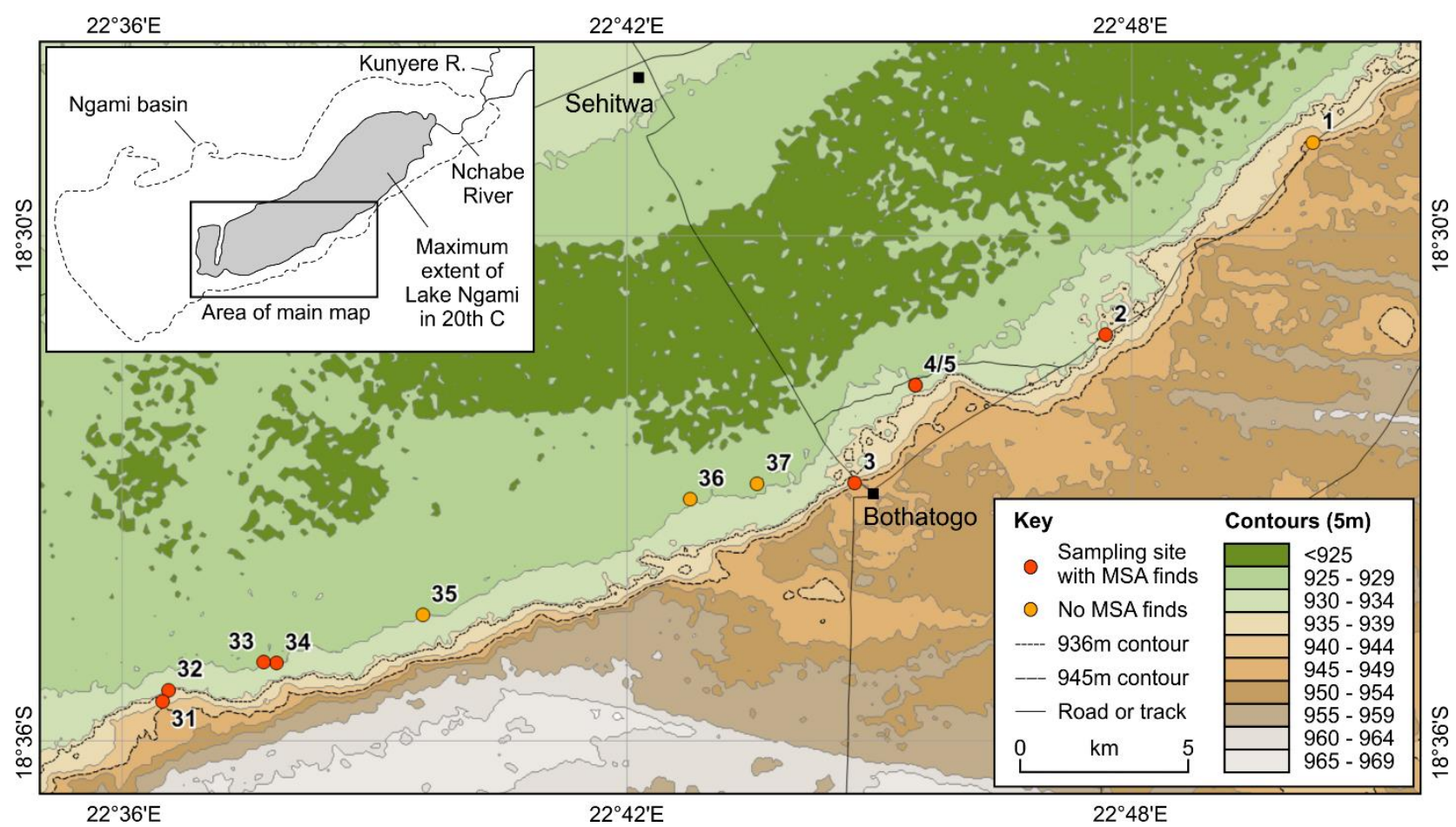

Figure 12. Positions of silcrete sampling sites BOT11/1-5 and BOT11/31-37 around the southern margin of Lake Ngami plotted against Shuttle Radar Topographic Mission (SRTM1) altitudinal data. Inset shows the location of the main map within the Ngami basin. Base map created by Frank Eckardt. 
Table 1. Key influences upon human mobility inferred from studies of lithic raw material procurement patterns and ethnographic data.

\begin{tabular}{|c|c|}
\hline Influences upon mobility & Example studies \\
\hline $\begin{array}{l}\text { Availability and location of raw material sources-these } \\
\text { influence the distance over which lithic raw material is } \\
\text { transported }\end{array}$ & $\begin{array}{l}\text { (Binford, 1979, 1980; Kelly, 1988; Bamforth, 1990; Tankersley, 1991; Andrefsky, 1994, 2007, 2009; Barut, } \\
\text { 1994; Merrick et al., 1994; Ambrose, 2001a, b, 2002, 2006, 2012; Beck et al., 2002; Brantingham, 2003, 2006; } \\
\text { Jones et al., 2003; Kuhn, 2004; Minichillo, 2006; Browne and Wilson, 2013; Barton and Riel-Salvatore, 2014; } \\
\text { Ekshtain et al., 2014; Pleurdeau et al., 2014; Boulanger et al., 2015) }\end{array}$ \\
\hline $\begin{array}{l}\text { Mobility costs- these influence distance-decay curves or drop- } \\
\text { off rates, at what chaîne opératoire stage artefacts are } \\
\text { transported, as well as rates of tool use/discard and } \\
\text { retouch/recycling }\end{array}$ & $\begin{array}{l}\text { (Koerper et al., 1987; Shackley, 1987; Féblot-Augustins, 1993, 1997; Blades, 1999; Ambrose, 2001a, 2006, } \\
\text { 2012; Wallace and Shea, 2006; Amick, 2007; Blumenschine et al., 2008; Andrefsky, 2009; Brown, 2011; } \\
\text { Clarkson and Bellas, 2014; Pleurdeau et al., 2014) }\end{array}$ \\
\hline $\begin{array}{l}\text { Raw material quality and preference-these influence the } \\
\text { choice of raw material transported }\end{array}$ & $\begin{array}{l}\text { (Gould and Saggers, 1985; Bamforth, 1990; Brantingham et al., 2000; Jones et al., 2003; Minichillo, 2006; } \\
\text { Wilson, 2007; Wurz, 2010; Porraz et al., 2013a; Gopher and Barkai, 2014; Pleurdeau et al., 2014) }\end{array}$ \\
\hline $\begin{array}{l}\text { Planning depth, risk sensitivity, and stone-tool production } \\
\text { effort—-these influence procurement patterns and their variation }\end{array}$ & (Roebroeks et al., 1988; Geneste, 1989; Beck et al., 2002; Ambrose, 2006; Brantingham, 2006) \\
\hline $\begin{array}{l}\text { Seasonal rounds, group mobility, and foraging strategy-these } \\
\text { influence when and who is involved in raw material } \\
\text { procurement }\end{array}$ & $\begin{array}{l}\text { (Binford, 1980; Gould and Saggers, 1985; Shott, 1986; Kelly, 1988; Ambrose and Lorenz, 1990; Rensink et al., } \\
\text { 1991; Porraz et al., 2008; Browne and Wilson, 2013) }\end{array}$ \\
\hline $\begin{array}{l}\text { Territoriality-this can influence raw material source } \\
\text { availability }\end{array}$ & $\begin{array}{l}\text { (Féblot-Augustins, 1999; Jones et al., 2003; McCall, 2007; Fernandes et al., 2008; Bamforth, 2009; Aubry et al., } \\
\text { 2012) }\end{array}$ \\
\hline $\begin{array}{l}\text { Regional interaction, exchange, and social networks - these can } \\
\text { influence transport distance and resource acquisition through } \\
\text { direct or indirect means }\end{array}$ & $\begin{array}{l}\text { (Cottrell, 1985; Meltzer, 1989; Féblot-Augustins, 1999; Ambrose, 2001a, b, 2002, 2006, 2012; Baales, 2001; } \\
\text { Marwick, 2003; Brantingham, 2006; Whallon, 2006; Wilkins, 2010; Aubry et al., 2012; Porraz et al., 2013a; } \\
\text { Boulanger et al., 2015) }\end{array}$ \\
\hline $\begin{array}{l}\text { Sociocultural factors - these can influence the use or choice of } \\
\text { raw material sources. Examples include taboo, ancestral ties, } \\
\text { resource ownership, colour preference, sources of power, } \\
\text { symbolic connotations, and raw material choice as a cultural } \\
\text { marker. }\end{array}$ & $\begin{array}{l}\text { (White and Thomas, 1972; Taçon, 1991; Paton, 1994; Wurz, 1999; Harrison, 2002; Stout, 2002; Ross et al., } \\
\text { 2003; Tykot, 2003; Barham, 2005; Tibbett, 2006; Akerman, 2007; Eerkens et al., 2007; Dillian and White, } \\
\text { 2010; Aubry et al., 2012; Speth et al., 2013) }\end{array}$ \\
\hline
\end{tabular}


Table 2. Details of silcrete manufacturing waste flakes from the MSA layers of Corner Cave, Tsodilo Hills, selected for geochemical analysis. ${ }^{\text {a }}$

\begin{tabular}{|c|c|c|c|c|c|c|c|c|}
\hline $\begin{array}{l}\text { Sample } \\
\text { ID }\end{array}$ & Unit & $\begin{array}{c}\text { Maximum } \\
\text { length }(\mathbf{m m})\end{array}$ & $\begin{array}{c}\text { Maximum } \\
\text { width }(\mathrm{mm})\end{array}$ & \begin{tabular}{c|} 
Maximum \\
thickness $(\mathrm{mm})$
\end{tabular} & Weight (g) & $\begin{array}{l}\text { Silcrete type } \\
\text { group }\end{array}$ & Description & Potential source area \\
\hline CC-1 & CC $1 / 456-58 \mathrm{~cm}$ & 26 & 15 & 5 & 2.12 & 1B & Flake fragment & Unknown \\
\hline CC-2 & CC $2 / 374-76 \mathrm{~cm}$ & 23 & 12 & 6 & 1.42 & $1 \mathrm{~B}$ & Flake fragment & Unknown \\
\hline $\mathrm{CC}-3$ & CC 2/7 82-84 cm & 25 & 23 & 7 & 3.90 & 1B & Flake & Unknown $^{c}$ \\
\hline CC-4 & CC 2/15 98-100 cm & 18 & 13 & 4 & 1.08 & 1B & Flake fragment & Unknown \\
\hline CC-5 & CC 1/10 68-70 cm & 29 & 27 & 6 & 5.60 & $2 \mathrm{~A}$ & Flake & Lake Ngami $^{\mathrm{b}}$ \\
\hline CC-6 & CC 2/4 76-78 cm & 28 & 16 & 5 & 1.98 & $2 \mathrm{~A}$ & Flake fragment & Lake Ngami ${ }^{\mathrm{b}}$ \\
\hline CC-7 & CC $2 / 680-82 \mathrm{~cm}$ & 20 & 15 & 8 & 1.76 & $2 \mathrm{~A}$ & Flake & Unknown $^{c}$ \\
\hline CC-8 & CC $2 / 986-88 \mathrm{~cm}$ & 21 & 15 & 5 & 1.80 & $2 \mathrm{~B}$ & Flake fragment & Unknown \\
\hline CC-9 & CC 2/10 88-90 cm & 26 & 18 & 8 & 3.00 & $2 \mathrm{~B}$ & Flake fragment & Unknown \\
\hline CC-10 & CC 2/14 96-98 cm & 22 & 19 & 6 & 1.80 & $2 \mathrm{~B}$ & Flake & Unknown $^{\mathrm{d}}$ \\
\hline $\mathrm{CC}-11$ & CC 2/14 96-98 cm & 24 & 22 & 6 & 3.50 & $\overline{2 B}$ & Flake & Unknown $^{\mathrm{d}}$ \\
\hline $\mathrm{CC}-12$ & CC $2 / 578-80 \mathrm{~cm}$ & 36 & 32 & 17 & 15.79 & $3 \mathrm{~A}$ & Flake fragment & Lake Ngami ${ }^{\text {b }}$ \\
\hline CC-13 & CC 2/14 96-98 cm & 31 & 21 & 8 & 5.73 & $3 \mathrm{~A}$ & Flake fragment & Lake Ngami ${ }^{\mathrm{b}}$ \\
\hline CC-14 & CC 2/10 88-90 cm & 22 & 18 & 4 & 1.50 & $3 \mathrm{~B}$ & Flake fragment & Boteti River ${ }^{b}$ \\
\hline $\mathrm{CC}-15$ & CC $2 / 578-80 \mathrm{~cm}$ & 41 & 19 & 5 & 4.06 & $3 \mathrm{D}$ & Flake & Unknown $^{\mathrm{c}}$ \\
\hline CC-16 & CC $2 / 782-84 \mathrm{~cm}$ & 25 & 23 & 6 & 3.10 & $3 \mathrm{D}$ & Flake fragment & Lake Ngami $^{\text {b }}$ \\
\hline CC-17 & CC $1 / 1068-70 \mathrm{~cm}$ & 20 & 13 & 10 & 2.51 & $4 \mathrm{~A}$ & Flake & Boteti River $^{\mathrm{b}}$ \\
\hline CC-18 & CC $2 / 578-80 \mathrm{~cm}$ & 20 & 16 & 3 & 1.06 & $4 \mathrm{~A}$ & Flake & Boteti River ${ }^{\mathrm{b}}$ \\
\hline CC-19 & CC $2 / 680-82 \mathrm{~cm}$ & 19 & 15 & 4 & 1.50 & $4 \mathrm{~A}$ & Flake fragment & Boteti River ${ }^{\mathrm{b}}$ \\
\hline $\mathrm{CC}-20$ & CC $2 / 782-84 \mathrm{~cm}$ & 29 & 19 & 8 & 2.67 & $4 \mathrm{~A}$ & Flake fragment & Lake Ngami ${ }^{\text {b }}$ \\
\hline CC-21 & CC $2 / 986-88 \mathrm{~cm}$ & 25 & 16 & 4 & 1.79 & $4 \mathrm{~A}$ & Flake fragment & Boteti River $^{b}$ \\
\hline CC-22 & CC $2 / 1088-90 \mathrm{~cm}$ & 22 & 18 & 4 & 1.40 & $4 \mathrm{~A}$ & Flake & Lake Ngami $^{\mathrm{b}}$ \\
\hline CC-23 & CC $1 / 1476-78 \mathrm{~cm}$ & 24 & 22 & 6 & 2.78 & $4 \mathrm{~B}$ & Flake fragment & Unknown $^{\mathrm{d}}$ \\
\hline $\mathrm{CC}-24$ & CC $2 / 680-82 \mathrm{~cm}$ & 20 & 11 & 6 & 1.49 & $4 \mathrm{~B}$ & Flake fragment & Okavango River ${ }^{\mathrm{b}}$ \\
\hline CC-25 & CC 2/13 94-96 cm & 26 & 25 & 13 & 9.17 & 6 & Flake & Unknown \\
\hline CC-26 & CC 2/17 102-104 & 30 & 22 & 11 & 6.68 & 6 & Flake fragment & Boteti River $^{\mathrm{b}}$ \\
\hline
\end{tabular}

${ }^{a}$ See SOM Table S1 for details of silcrete type groups

${ }^{\mathrm{b}}$ Significant at $p \leq 0.01$ - see text for explanation

${ }^{c}$ But marginal to Lake Ngami cluster

${ }^{\mathrm{d}}$ But marginal to Boteti River cluster 
Table 3. Details of silcrete manufacturing waste flakes from the MSA layers of Rhino Cave, Tsodilo Hills, selected for geochemical analysis. ${ }^{\text {a }}$

\begin{tabular}{|c|c|c|c|c|c|c|c|c|}
\hline $\begin{array}{l}\text { Sample } \\
\text { ID }\end{array}$ & Unit & $\begin{array}{c}\text { Maximum } \\
\text { length }(\mathrm{mm})\end{array}$ & $\begin{array}{l}\text { Maximum } \\
\text { width (mm) }\end{array}$ & $\begin{array}{c}\text { Maximum } \\
\text { thickness (mm) }\end{array}$ & Weight (g) & $\begin{array}{c}\text { Silcrete } \\
\text { type group }\end{array}$ & Description & $\begin{array}{c}\text { Potential source } \\
\text { area }\end{array}$ \\
\hline $\mathrm{RC}-2$ & Pit $3,90-95 \mathrm{~cm}$ & 27 & 20 & 5 & 4 & $4 \mathrm{~B}$ & Flake fragment & Boteti River ${ }^{b}$ \\
\hline RC-4 & Pit 3, 65-70 cm & 26 & 22 & 5 & 3 & $4 \mathrm{~T}$ & Flake & Unknown \\
\hline$\overline{\mathrm{RC}-5}$ & Pit 3, 65-70 cm & 24 & 16 & 6 & 3 & $4 \mathrm{~T}$ & Flake fragment & Unknown \\
\hline RC-6 & Pit $3,55-60 \mathrm{~cm}$ & 39 & 25 & 9 & 8 & $4 \mathrm{~A}$ & Flake & Unknown $^{\mathrm{d}}$ \\
\hline RC-9 & $\begin{array}{l}\text { Quad V, level } 29 \\
\text { c. } 143-150 \mathrm{~cm}^{\mathrm{e}}\end{array}$ & 30 & 16 & 8 & 5 & $4 \mathrm{~L}$ & Flake & Unknown $^{\mathrm{d}}$ \\
\hline RC-10 & Pit 3, 45-50 cm & 29 & 20 & 11 & 4 & $4 \mathrm{E}$ & Flake fragment & Unknown \\
\hline RC-11 & $\begin{array}{l}\text { Quad W, level } 28 \\
\text { c. } 137-143 \mathrm{~cm}^{\mathrm{e}}\end{array}$ & 30 & 32 & 9 & 9 & $4 \mathrm{E}$ & Flake & Unknown $^{\mathrm{d}}$ \\
\hline $\mathrm{RC}-12$ & $\begin{array}{l}\text { Quad TT, level 5 } \\
\text { c. } 119-124 \mathrm{~cm}^{\mathrm{e}}\end{array}$ & 23 & 20 & 13 & 8 & $4 \mathrm{~S}$ & Flake fragment & Unknown $^{\mathrm{d}}$ \\
\hline RC-17 & Quad VW, 165-170 cm & 32 & 19 & 6 & 4 & $\overline{4 \mathrm{H}}$ & Flake fragment & Unknown $^{\mathrm{d}}$ \\
\hline RC-18 & Ouad RS, $160-165 \mathrm{~cm}$ & 26 & 25 & 10 & 4 & $4 \mathrm{H}$ & Flake fragment & Unknown $^{\mathrm{d}}$ \\
\hline
\end{tabular}

${ }^{a}$ See SOM Table S1 for details of silcrete type groups

${ }^{\mathrm{b}}$ Significant at $p \leq 0.01$ - see text for explanation

${ }^{\mathrm{c}}$ But marginal to Lake Ngami cluster

${ }^{\mathrm{d}}$ But marginal to Boteti River cluster

${ }^{\mathrm{e}}$ Estimated depths 
Table 4. Details of silcrete manufacturing waste flakes from the MSA layers of $\neq$ Gi, near Aha Hills selected for geochemical analysis.

\begin{tabular}{|c|c|c|c|c|c|c|c|}
\hline $\begin{array}{l}\text { Sample } \\
\text { ID }\end{array}$ & Unit & $\begin{array}{c}\text { Maximum } \\
\text { length }(\mathbf{m m})\end{array}$ & $\begin{array}{c}\text { Maximum } \\
\text { width }(\mathrm{mm})\end{array}$ & $\begin{array}{c}\text { Maximum } \\
\text { thickness }(\mathbf{m m})\end{array}$ & Weight (g) & Description & Potential source area \\
\hline$\neq \mathrm{Gi}-3$ & $120-130 \quad 48$ 5/6 W BD & 29 & 21 & 6 & 4.41 & Flake fragment & Unknown \\
\hline$\neq \mathrm{Gi}-5$ & $120-130 \quad 485 / 6 \mathrm{~W}$ BD & 27 & 19 & 8 & 4.10 & Flake fragment & Unknown \\
\hline$\neq \mathrm{Gi}-6$ & $120-130 \quad 485 / 6 \mathrm{~W}$ BD & 23 & 18 & 8 & 3.45 & Flake fragment & Unknown \\
\hline$\neq \mathrm{Gi}-7$ & $120-130 \quad 48$ 5/6 W BD & 23 & 21 & 8 & 3.25 & Flake & Unknown \\
\hline$\neq$ Gi -9 & $120-130 \quad 56 / 8 \quad 12 / 11 \mathrm{D}$ & 23 & 21 & 9 & 4.62 & Flake & Unknown \\
\hline$\neq \mathrm{Gi}-10$ & $120-130 \quad 56 / 8$ 12/11 A & 47 & 36 & 16 & 19.38 & Knapping fragment & Unknown \\
\hline$\neq \mathrm{Gi}-11$ & $120-130 \quad 56 / 8$ 12/11 A & 40 & 24 & 7 & 5.30 & Flake & Unknown $^{\mathrm{b}}$ \\
\hline$\neq \mathrm{Gi}-12$ & $\begin{array}{l}120-130 \quad 56 / 812 / 13 \mathrm{C} \\
\text { dark }+ \text { alluv- sand }\end{array}$ & 39 & 26 & 9 & 7.43 & Flake & Unknown \\
\hline$\neq \mathrm{Gi}-13$ & $\begin{array}{l}120-13056 / 8 \text { 12/13 C } \\
\text { dark + alluv- sand }\end{array}$ & 32 & 29 & 8 & 6.16 & Flake fragment & Unknown \\
\hline$\neq \mathrm{Gi}-15$ & $120-130 \quad 56 / 8$ 12/14 B & 29 & 22 & 6 & 4.11 & Flake fragment & Boteti River $^{\text {a }}$ \\
\hline$\neq \mathrm{Gi}-17$ & $\begin{array}{l}120-130 \quad 56 / 812 / 14 \mathrm{D} \\
\text { dark + alluv- sand }\end{array}$ & 47 & 32 & 12 & 15.48 & Flake fragment & Unknown $^{\mathrm{b}}$ \\
\hline$\neq \mathrm{Gi}-18$ & $130-140 \quad 56 / 8 \quad 12 / 14 \mathrm{~A}$ & 34 & 29 & 8 & 7.32 & Flake fragment & Unknown \\
\hline$\neq \mathrm{Gi}-19$ & $130-140 \quad 56 / 8 \quad 12 / 14 \mathrm{~A}$ & 29 & 23 & 13 & 7.02 & Flake fragment & Unknown \\
\hline$\neq \mathrm{Gi}-21$ & $130-140 \quad 56 / 8 \quad 12 / 14 \mathrm{C}$ & 39 & 26 & 18 & 13.85 & Knapping fragment & Unknown \\
\hline$\neq \mathrm{Gi}-22$ & $130-140 \quad 56 / 8 \quad 12 / 14 \mathrm{C}$ & 35 & 27 & 6 & 7.17 & Flake fragment & Unknown \\
\hline$\neq \mathrm{Gi}-24$ & $130-140 \quad 56 / 8$ 12/14/82 D & 40 & 29 & 11 & 8.90 & Flake & Unknown \\
\hline$\neq \mathrm{Gi}-25$ & $140-150 \quad 485 / 6 \mathrm{~W}$ & 45 & 30 & 8 & 9.08 & Flake fragment & Unknown \\
\hline$\neq \mathrm{Gi}-26$ & $150-160 \quad 485 / 6 \mathrm{~W}$ BD & 45 & 34 & 14 & 17.92 & Flake & Unknown \\
\hline$\neq \mathrm{Gi}-27$ & $150-160 \quad 485 / 6 \mathrm{~W}$ BD & 50 & 42 & 13 & 28.02 & Flake & Unknown \\
\hline$\neq \mathrm{Gi}-28$ & $150-160485 / 6 \mathrm{~W}$ BD & 47 & 42 & 10 & 14.30 & Flake fragment & Unknown \\
\hline$\neq \mathrm{Gi}-29$ & $150-160 \quad 485 / 6 \mathrm{~W}$ BD & 31 & 30 & 8 & 8.28 & Flake fragment & Unknown \\
\hline$\neq \mathrm{Gi}-30$ & $150-160 \quad 485 / 6 \mathrm{~W}$ BD & 29 & 17 & 10 & 6.57 & Flake & Unknown \\
\hline$\neq \mathrm{Gi}-34$ & $150-160 \quad 48 /-611 / 26 \mathrm{D}$ & 41 & 32 & 10 & 9.00 & Knapping fragment & Boteti River $^{\text {a }}$ \\
\hline$\neq \mathrm{Gi}-35$ & $150-160 \quad 48 /-611 / 26 \mathrm{D}$ & 55 & 32 & 11 & 16.28 & Flake fragment & Unknown \\
\hline
\end{tabular}

${ }^{a}$ Significant at $p \leq 0.01-$ see text for explanation

${ }^{\mathrm{b}}$ But marginal to Boteti River cluster 